NBER WORKING PAPER SERIES

THE ANATOMY OF FINANCIAL CRISES

Barry Eichengreen

Richard Portes

Working Paper No. 2126

NATIONAL BUREAU OF ECONOMIC RESEARCH

1050 Massachusetts Avenue

Cambridge, MA 02138

January 1987

\begin{abstract}
Paper prepared for the conference on "Risk, International Financial Markets, and Public Policy" organised by the International Center for Monetary and Banking Studies, Geneva, 11-13 September 1986, in collaboration with the Centre for Economic Policy Research. We thank H.M. Stationary office for permission to cite documents from the Public Record Office, Anita Santorum for research assistance, and Jane Maurice for cheerful secretarial help beyond the call of duty. Anthony Harris, Joan Pearce and our discussants offered very useful comments, as did the seminar group at the Institute for International Economic Studies (Stockholm), where an early version of the work was presented in Apri1 1986. The paper will appear in R. Portes and A. Swoboda, eds., Threats to International Financial Stability, Cambridge University Press, 1987. This paper is part of a research program on Macroeconomic Interactions and Policy Design in an Interdependent World supported by grants from the Ford Foundation (No. 850-1014) and the Alfred P. Sloan Foundation (No. 85-12-13) whose help is gratefully acknowledged. The research reported here is part of the NBER's research program in International studies. Any opinions expressed are those of the authors and not those of the National Bureau of Economic Research.
\end{abstract}


A financial crisis is a disturbance to financial markets. associated typically with falling asset prices and insolvency among debtors and intermediaries, which spreads through the financial system, disrupting the market's capacity to allocate capital. In this paper we analyze the generation and propagation of financial crises in an international setting. We provide a perspective on the danger of a serious disruption to the glohal financial system by comparing the last full-fledged financial crisis - that of the 1930s - with conditions prevailing todav.

Our definition of a financial crisis implies a distinction between generalized financial crises on the one hand and isolated bank failures, debt defaults and foreign-exchange market disturbances on the other. We represent this distinction in three sets of linkages: between debt defaults; and between exchange-market disturbances and bank failures.

In both the 1930 s and 1980s, the institutional environment was drastically altered by ranid change in foreign exchange markets, in international capital markets, and in the structure of. domestic banking systems. Our comparative analysis underscores the critical role played by institutional arrangements in financial markets as a determinant of the system's vulnerability to destabilizing shocks.

Barry Eichengreen Department of Economics Harvard University Cambridge, MA 02138
Richard Portes

Director

Centre for Economic Policy Research

6 Duke of York Street

London SWIY 6LA ENGLAND 


\section{The Anatomy of Financial Crises}

Barry Eichengreen and Richard Portes

December 1986

Much as the study of disease is one of the most effective ways to learn about human biology, the study of financial crises provides one of the most revealing perspectives on the functioning of monetary economies. Indeed, epidemiological metaphors like fever and contagion feature prominently in the literature on financial crises. Financial crises, like contagious disease, threaten not only the host organism, namely the financial market, but the entire economic environment in which that host resides.

There exists a voluminous historical literature concerned with episodes labelled financial crises. ' Yet the usefulness of much of this literature is limited by the absence of any definition of the phenomenon under consideration and hence of a minimal structure around which historical observation can be organized.? This criticism is not limited to the historical literature, since recent theoretical analyses of financial crises are uniformly deficient in this same regard. While no single definition may be appropriate to all purposes, any work on financial crises should proceed on the basis of an explicit statement of meaning. Since our purpose in this paper is to provide a perspective on the present and prospective danger of a serious disruption to the global financial system, which we propose to explore by comparing the last fullfledged financial crisis - that of the 1930s - with conditions prevailing today, we adopt the following definition. A financial 
crisis is a disturbance to financial markets, associated typically with falling asset prices and insolvency among debtors and intermediaries, which ramifies through the financial system, disrupting the market's capacity to allocate capital within the economy. In an international financial crisis, disturbances spill over national borders, disrupting the market's capacity to allocate capital internationally.

This definition suggests an agenda for research, of which the following questions form only a part. What are the distinguishing features of disturbances which give rise to financial crises?

Rather than the nature of the disturbances, is it the financial system's response that differentiates crises from perturbations to financial markets? What is the mechanism through which a disturbance specific to a single market is generalized to the entire system? In particular, what are the roles of asset prices and solvency problems in the processes of generalization and propagation? How are the market's allocative capacities disrupted, and what are the implications of this disruption for the course of the crisis itself?

Our definition implies a distinction between generalized financial crises on the one hand and bank failures, debt defaults and foreign-exchange market disturbances on the other. This distinction is the presence of linkages, which are represented schematically in Figure 1. These linkages within the body economic give the essential anatomy of financial crises. Consider two examples which play a leading role in our historical analysis. Defaults on sovereign bonds, if sufficiently 
Figure 1. Asset - Market Linkages

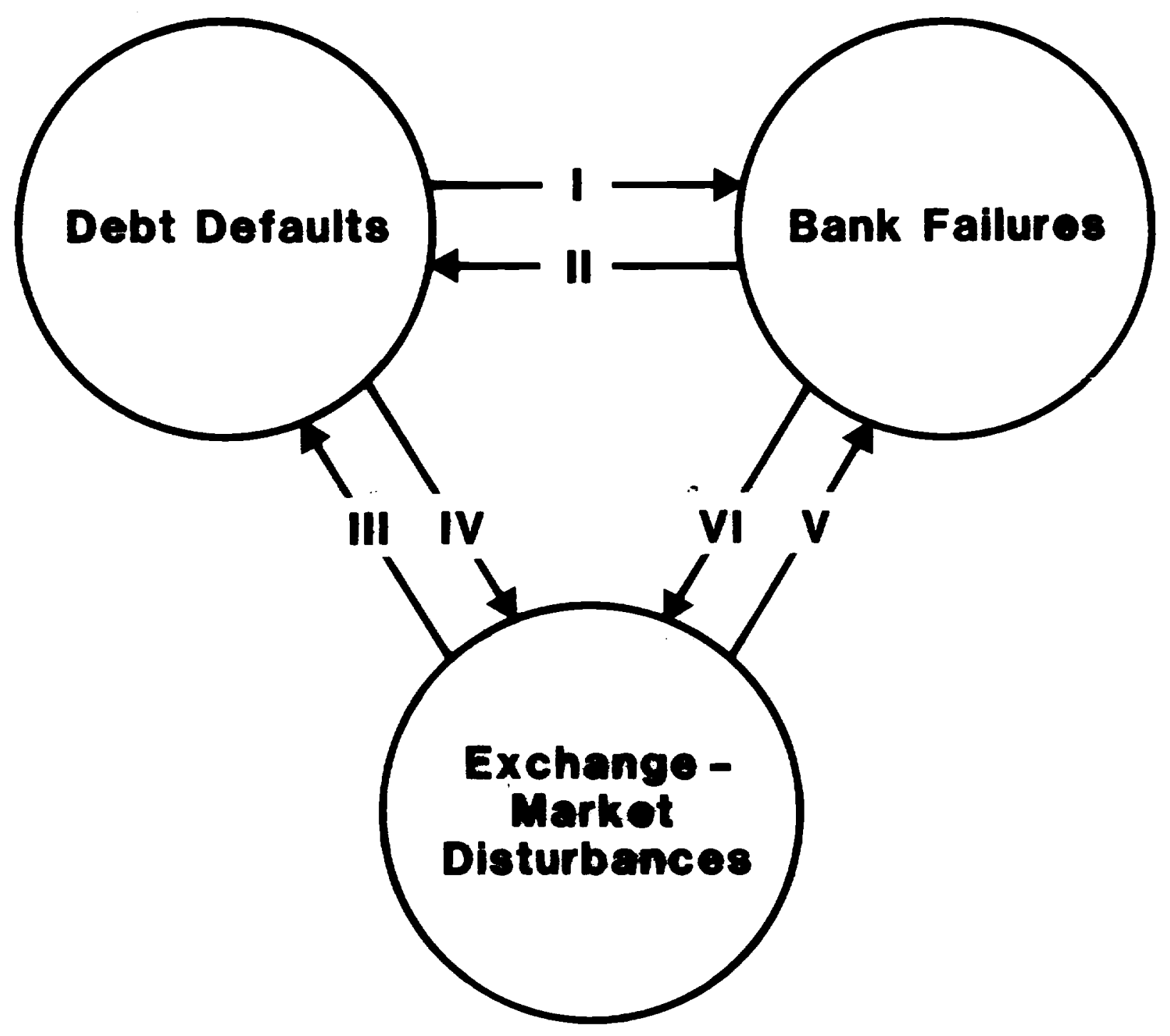


widespread and disruptive, impede the ability of the bond market to allocate capital across countries. But if these defaults are not accompanied by bank failures (if in Figure 1 the linkage labelled "I" is interrupted), there may exist alternative channels, notably bank loans, through which the capital market's allocative functions may be carried out. Debt default need not give rise to financial crisis. But if, on the contrary, debt default heightens the commercial banks' susceptibility to failure, the danger of a generalized crisis is intensified. To take another example, an anticipated devaluation may threaten the banking system if depositors liquidate their accounts in an effort to avoid capital losses on their overseas assets (an example of the linkage labelled "V"); but if they hold government securities instead, this linkage is broken and exchange-market difficulties need not be associated with financial collapse. Clearly, the extent and speed of transmission allong these linkages depend on institutional arrangements in financial markets, including any institutionalized responses of policy-makers.

In this paper, we focus on the generalization and propagation of financial crises in an international setting. Ideally, these issues of generalization and propagation are studied historically: while all serious disturbances threaten the stability of financial institutions, it is only from the comparison of historical episodes during which different institutional arrangements prevailed that generalizations about the fragility or resilience of monetary economies can be derived. By analyzing the contrasting institutional arrangements of the $1930 \mathrm{~s}$ and $1980 \mathrm{~s}$, we hope to 
identify configurations which render the international financial system particularly susceptible to collapse.

Our analysis of the generalization of financial disturbances underscores the critical role played by institutional arrangements in financial markets as a determinant of the system's vulnerability to destabilizing shocks. In both the $1930 \mathrm{~s}$ and $1980 \mathrm{~s}$, the institutional environment was drastically altered by rapid change in foreign exchange markets, in international capital markets, and in the structure of domestic banking systems. But the implications of institutional changes have not all been similar. In the earlier period, they generally worked in the direction of heightening the system's vulnerability to shocks; recently, however, some have tended to work in the opposite direction. Our review of the course of crises suggests that the banking system and the linkages by which it is connected to the rest of the financial sector play a pivotal role in the propagation of crises. Our analyses highlight the importance of two sets of factors in the process of propagation: asset-market linkages running from debt defaults and exchange-market disturbances to the stability of the banking system (Iinkages I and $V$ in Figure 1), and the role of economic policy in blocking these linkages and thereby insulating the banking system and the macroeconomy from threats to their stability. 
I. The International Financial Crisis of the 1930s

\section{A. The Environment}

The 1920s were marked by three sets of developments which increased the international financial system's susceptibility to destabilizing shocks: flux in the foreign exchange market, rapid institutional change in the banking system, and dramatic shifts in the volume and direction of international lending. Each set of developments had its immediate origins in the dislocations associated with World War $I$.

\section{Foreign Exchange Markets}

The war and its aftermath marked the end of the classical gold standard. Most countries initially succeeded in maintaining their gold reserves and customary exchange rates by withdrawing gold coin from circulation and embargoing bullion shipments. But as hostilities dragged on and were financed through the issue of money and bonds, pressure mounted in foreign exchange markets. The German and Austrian exchanges collapsed by 1918. The British and French rates were propped up by American intervention but depreciated with the termination of support in 1919.3 The postwar inflationary boom, the reparations tangle and deficit finance of reconstruction all wreaked havoc with national efforts to peg the domestic-currency price of gold.

Policymakers then confronted the question of the appropriate level at which to stabilize exchange rates. The history of subsequent efforts to reconstruct the system of fixed parities is familiar: Britain restored sterling's prewar parity in 1925 following a period of deflation; France opted against reversing half 
a decade of inflation, pegging the franc price of gold at five times the prewar level; Germany and other countries experiencing hyperinflation established new currency units; and Latin American countries reestablished gold standard parities in conjunction with budgetary reforms and newly independent central banks. 4

The characteristics of the reconstructed gold standard added to the strains on the financial system. Paramount was the problem of misalignment, starting with the pound sterling, the traditional linchpin of the monetary mechanism. Due to high wages and to changes in the direction of trade, Britain's restoration of the prewar parity rendered the pound overvalued and difficult to defend with the Bank of England's slender reserves. Keynes (1925) estimated sterling's overvaluation at $10-15$ per cent. In conventional accounts, an undervalued French franc figures also among the misaligned currencies. 5 Misalignment was related to the problem of maldistributed gold reserves, which came to be concentrated in the United States and France. This maldistribution gave rise elsewhere to complaints of a "gold shortage", which induced countries to expand on prewar practice and supplement gold reserves with foreign deposits. The growth of foreign deposits rendered the reserve currencies increasingly vulnerable to destabilizing shocks. 6 Each of these difficulties reflected the failure of governments to coordinate their choice of exchange rates and to harmonize their monetary policies. Ultimately, the consequences of this failure would be far reaching. $6 a$ 


\section{International Lending}

The impact of the war on patterns of international lending and borrowing was equally profound. 7 The 1920 s marked the rise of the United States and decline of Britain as external creditors. The transfer of business from London to New York, initiated by wartime closure of the Jondon market to foreign borrowers and by the Liberty Loan campaign in the United states, was reinforced following the conclusion of hostilities by informal capital controls in the UK and abundant savings in the US. Before the war, Britain's foreign assets roughly matched the combined total of the remaining creditor countries, while the US was a creditor of negligible importance. In the 1920s (with the exception of 1923, when transfers to Europe were depressed by the Ruhr invasion), lending by the US, especially to countries outside the British Fmpire, consistently exceeded that by Britain.

The other side of this coin was rapidly mounting indebtedness in Central Furope and Latin America. Loans to Furope were used to finance the reconstruction of industry and infrastructure, the purchase of imported inputs and the provision of working capital. At the same time, the growth of lending can be understood as a response to the need to recycle German reparations in much the same way that OPEC investment in the US, in conjunction with US lending to LDCs, recycled oil revenues in the 1970s. 8 Loans to Latin America, in contrast, reflected favorable publicity and growing awareness of economic prospects in developing regions. 9 Table 1 summarizes the direction of US and British lending. American lending was widely distributed, going most heavily to Europe (where 


\section{U.S. and British Lending in the 1920s}

U.S. Lending Abroad, by Region

(millions of dollars)

Europe Canada Latin America Far East

1924

526.6

151.6

187.0

96.1

1925

629.5

$137 \cdot 1$

158.8

141.7

1926

484.0

226.3

368.2

31.7

1927

$557 \cdot 3$

236.4

339.7

151.2

1928

597.9

184.9

330.1

130.8

1929

142.0

289.7

175.0

51.5

British Investment in Goverment and Municipal Securities (millions of pounds)

$\begin{array}{ccc} & \text { Foreign } & \text { Dominion and Colonial } \\ 1926 & 392.0 & 676.5 \\ 1927 & 406.7 & 703.3 \\ 1928 & 364.5 & 1036.0 \\ 1929 & 351.0 & 1061.6\end{array}$

Sources: For the U.S., Department of Commerce (1930); for Britain, Royal Institute of Intemational Affairs (1937). 
Anmual Growth Rates of Real GDP, Industrial Production and Exports 1925-1929, and Debt/Export Ratio, 1929

(in percentage points)

\begin{tabular}{|c|c|c|c|c|}
\hline & GDP & $\begin{array}{l}\text { Industrial } \\
\text { Production }\end{array}$ & $\begin{array}{l}\text { Exports } \\
\text { in US } \\
\text { Dollars }\end{array}$ & $\begin{array}{l}1929 \\
\text { Central Govt. } \\
\text { Forelgn Debt as } \\
\text { Percent of } \\
\text { Exports } \\
\end{array}$ \\
\hline Germany & 1.7 & 5.0 & 9.9 & 6.6 \\
\hline Austria & 2.7 & 6.3 & 4.0 & 77.5 \\
\hline Hungary & 7.1 & $-0.4^{*}$ & 5.9 & 123.2 \\
\hline Australia & -0.4 & 4.1 & -3.8 & 112.5 \\
\hline Canada & $6.3^{*}$ & 8.8 & -1.1 & 46.2 \\
\hline Argentina & $5 \cdot 7$ & 5.2 & 4.8 & 41.8 \\
\hline Braz11 & 7.2 & 4.6 & -1.6 & 66.3 \\
\hline Costa Rica & 0.2 & 1.6 & 3.1 & 95.4 \\
\hline Chile & 10.8 & 0.0 & 5.8 & 101.7 \\
\hline Colombia & 7.5 & 4.5 & 11.6 & 55.7 \\
\hline Honduras & 5.6 & 6.8 & 20.2 & 43.3 \\
\hline El Salvador & 1.7 & 5.9 & 12.4 & 105.4 \\
\hline Guatemala & 5.5 & 3.0 & -3.4 & 54.0 \\
\hline
\end{tabular}

Note: European figures exclude reparations. An asterisk indicates 1926-29. For Australia, industrial production is proxied by manufacturing production at constant prices.

Sources: Latin American figures computed from Thorp (1984), Appendix Table 4. European figures computed from Mitchell (1976). Canadian figures computed from Urquhart and Buckley (1964). Australian figures computed from Butiln (1985). 
Germany was the leading debtor in absolute terms) and then to Latin America and Canada; British lending was directed predominantly towards the Fmpire, especially at the end of the decade.

Then, as recently, there was much discussion of the soundness of foreign loans, embellished by tales of loan pushing, excessive commissions, corrupt administration, and squandering of funds. Indeed, placing much of the business in relatively inexperienced American hands may have increased the market's tendency to fund risky projects. 10 It is important to note, therefore, that the macroeconomic performance of the debtors, and the consequent growth in their ability to service external debt, was more than respectable, and in the latin American case rather impressive, during this period of large-scale foreign lending (1925-29). With the exception of Costa Rica and El Salvador, real GDP in those Latin American countries considered in Table 2 increased at then historically unprecedented rates in excess of five per cent per annum. Except for Brazil, Guatemala and (to a lesser extent) Costa Rica, the same is true of exports, despite a persistent decline in the prices of primary products. Initially, the ratio of debt service to exports (excluding reparations) remained manageable. $10 \mathrm{a}$

Thus, in the 1920s as in the 1970s, foreign lending was associated with expanding trade and rosy prospects, at least in the short run, for economic growth in the borrowing regions. Whether the loans were sound in the sense that export receipts would prove adequate to service them is essentially the question whether it was realistic to assume that the growth rates and financial stability (e.g., absence of real interest rate shocks) of the 1920s would 
persist. The answer is surely more obvious with hindsight than it was at the time.

\section{Banking Structure and Regulation}

These changes in the direction of foreign lending were accompanied by equally profound developments in the structure and regulation of commercial banking. Following the lead of the United States, which had created the Federal Reserve System in 1914, in the 1920 s many countries either established central banks or gave them added independence, in Latin America in conjunction with visits by US economic experts, in Central Europe as a condition of League of Nations stabilization loans. ${ }^{11}$ one function of these central banks was to act as lender of last resort, although as we shall see there was considerable variation in the effectiveness with which they carried out this role. In a number of countries monetary reform was accompanied by new banking regulations patterned on the US model. In Chile, for example, a law of september 1925 established a "Superintendencia de Bancos" charged with inspecting the books of banks and publishing a statement of their position annually. Banks were prohibited from extending individual loans in excess of ten per cent of the sum of paid-up capital and reserves and required to observe minimum capital requirements which differed by city size and liability composition. Since there was considerable variation in the appropriateness of the US model, these reforms varied in their efficacy and implications for the stability of national banking systems.

A number of countries including Germany and Poland established publicly owned or controlled agricultural credit and mortgage banks 
which engaged in all forms of deposit and industrial banking and expanded rapidly. ${ }^{12}$ Their implications for the stability of the financial system are not clear: on the one hand, public banks for political reasons sometimes extended loans for risky undertakings which did not attract private banks; on the other, the central authorities were particularly disinclined to let public enterprises fail.

A further feature of the development of banking structure in the 1920s was a pervasive amalgamation movement. While the immediate incentive for amalgamation was often savings on administrative costs, another advantage was the greater facility with which risk could be diversified and stability ensured through the dispersion of loans over different regions and sectors of the economy. Although present earlier, the amalgamation movement in commercial banking accelerated after World War I, spreading from England and Wales to Latin America, Hungary, Poland and Greece. In Germany and Czechoslovakia, large banks increasingly acquired control of their smaller counterparts, while in the US, restrictions on branch banking were circumvented through such mechanisms as the securities affiliate.

Along with the spread of the securities affiliate, financial innovation in the 1920 s took the form of the adoption of "investment" or "industrial" banking on a national scale in the Succession States of what had been the Austro-Hungarian Empire. In Fnglish-speaking, Scandinavian and Jatin American countries, intermediaries specialized in deposit banking, soliciting money on deposit and extending short-term advances to commerce and industry. 
The alternative of investment banking, which entailed long-term loans to industry, had traditionally prevailed in Central Europe. When the Succession states created new banking systems in the wake of World War I, they naturally emulated Austrian and German practice. Given the specialization of industry and agriculture in the newly partitioned Central European states, the fate of the banks' loan portfolios was tied to the fortunes of narrow industrial or agricultural markets. When a particular crop or industry was hit by the Depression, the shock to the banking system would prove severe.

\section{B. The Crisis and its Management}

Dur analysis of the financial crisis of the 1930s highlights two factors: first, the singular importance of linkages running from debt defaults and exchange market disturbances to the instability of banking systems; second, the critical role of policy in interrupting these linkages, thereby insulating the banking system and the macroeconomy from threats to their stability.

\section{Exchange Market Disturbances}

The first indication of serious financial distress was exchange-rate depreciation by primary producers starting in 1929 . While misalignments within the North Atlantic community may have played some role in early exchange-market difficulties, the most disruptive pressures originated on the real side, notably in markets for agricultural commodities and prinary products. So long as US import demands and foreign lending were maintained, these pressures remained tolerable. But in 1928-29 the indebted countries of 
Central Europe, Latin America and Oceania were subjected to dual shocks. First, the Wall street boom both reflected and induced portfolio shifts by US investors, choking off American capital exports: after peaking in the summer of 1928, they fell by 46 per cent within a year (see Table 1). Next, commodity exports declined precipitously following the U.S. cyclical downturn commencing in the summer of 1929 (see Table 3). Primary-producing countries were seriously affected (as shown in Table 4), since the U.S. accounted for more than 40 per cent of the primary-product consumption of the 15 leading industrial countries.

The exchange rate and the external debt were directly linked through the government's reserve constraint. Gold and foreignexchange reserves could be allocated either to debt service or to merchants and currency dealers who, under gold standard statutes, could demand gold for export. In principle, borrowing countries could have chosen to default on their external debts while defending the gold standard, to let their exchange rates go while maintaining debt service, or to default and depreciate simultaneously. Initially, they chose to sacrifice the exchange rate and honor the debt. One might speculate that policymakers viewed debt as even more sacrosanct than the gold standard, although that is doubtful in view of the frequency of default in the 19th century (matched only by the frequency of suspensions to convertibility). In fact, their motives were pragmatic: while default automatically precluded additional foreign borrowing, depreciation had less impact on credit-worthiness. It was even suggested that, insofar as depreciation stimulated exports, it might facilitate foreign bond 
TABLE 3

Business cycle indicators for advanced countries

\begin{tabular}{|c|c|c|c|c|c|}
\hline & GDP & $\begin{array}{l}\text { Import } \\
\text { volume }\end{array}$ & $\begin{array}{l}\text { Terms of } \\
\text { trade }\end{array}$ & $\begin{array}{l}\text { Net capital } \\
\text { outflow at } \\
1929 \text { prices } \\
\$ \text { million }\end{array}$ & $\begin{array}{c}\text { World price } \\
\text { level } \\
\text { (US export } \\
\text { unit values) }\end{array}$ \\
\hline $\begin{array}{l}1929 \\
1930 \\
1931 \\
1932 \\
1933 \\
1934 \\
1935 \\
1936 \\
1937 \\
1938\end{array}$ & $\begin{array}{r}100.0 \\
94.6 \\
89.3 \\
83.0 \\
84.0 \\
89.2 \\
94.3 \\
101.6 \\
107.0 \\
109.3\end{array}$ & $\begin{array}{r}100.0 \\
94.8 \\
89.5 \\
76.5 \\
78.4 \\
79.6 \\
81.8 \\
85.7 \\
97.4 \\
87.0\end{array}$ & $\begin{array}{l}100.0 \\
106.1 \\
111.8 \\
113.7 \\
114.8 \\
111.1 \\
108.0 \\
100.6 \\
103.9 \\
108.3\end{array}$ & 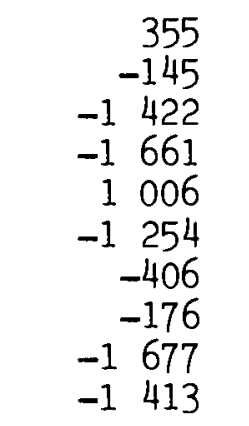 & $\begin{array}{r}100.0 \\
89.6 \\
69.4 \\
59.0 \\
61.9 \\
72.4 \\
74.6 \\
76.1 \\
80.6 \\
74.6\end{array}$ \\
\hline $\begin{array}{l}1973 \\
1974 \\
1975 \\
1976 \\
1977 \\
1978 \\
1979 \\
1980 \\
1981 \\
1982 \\
1983\end{array}$ & $\begin{array}{r}100.0 \\
100.4 \\
99.8 \\
105.1 \\
109.1 \\
113.5 \\
117.3 \\
118.8 \\
120.4 \\
119.9 \\
122.8\end{array}$ & $\begin{array}{r}100.0 \\
101.1 \\
92.7 \\
105.5 \\
109.5 \\
115.4 \\
124.0 \\
121.8 \\
118.4 \\
117.6 \\
122.0\end{array}$ & $\begin{array}{r}100.0 \\
88.4 \\
90.3 \\
89.8 \\
88.7 \\
91.1 \\
87.3 \\
81.3 \\
80.2 \\
81.9 \\
83.4\end{array}$ & $\begin{array}{rr}8 & 919 \\
7 & 020 \\
12 & 507 \\
12 & 416 \\
13 & 429 \\
17 & 241 \\
16 & 265 \\
14 & 215 \\
15 & 792 \\
14 & 340 \\
11 & 702\end{array}$ & $\begin{array}{l}100.0 \\
127.6 \\
142.6 \\
147.5 \\
152.7 \\
163.3 \\
185.9 \\
211.0 \\
230.4 \\
232.9 \\
236.5\end{array}$ \\
\hline
\end{tabular}

Notes: GDP import volume and terms of trade are weighted averages for 16 countries. The capital flows are deflated by the US export unit value index. The US export unit value in 1973 was 251 per cent of its 1929 level.

Source: Maddison (1985, p.13). 
TABLE 4

Business cycle indicators for 11 developing countries

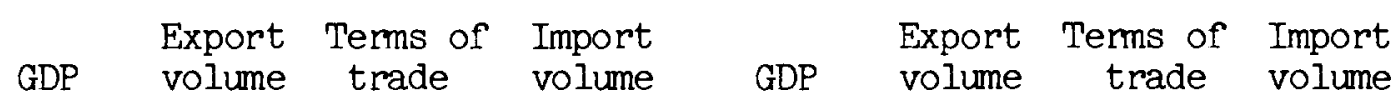

Latin America

Asia

\begin{tabular}{rrrrr|rrrr}
1929 & 100.0 & 100.0 & 100.0 & 100.0 & 100.0 & 100.0 & 100.0 & 100.0 \\
1930 & 96.1 & 81.2 & 81.5 & 77.4 & 101.1 & 91.3 & 90.4 & 89.5 \\
1931 & 90.0 & 90.0 & 67.9 & 51.9 & 101.4 & 86.6 & 83.5 & 82.3 \\
1932 & 86.7 & 73.0 & 71.4 & 39.5 & 103.8 & 77.7 & 84.2 & 78.5 \\
1933 & 93.2 & 75.7 & 68.8 & 45.5 & 104.5 & 80.0 & 82.1 & 71.2 \\
1934 & 101.0 & 85.4 & 76.5 & 52.5 & 99.4 & 82.6 & 86.6 & 76.7 \\
1935 & 106.3 & 91.9 & 75.2 & 56.4 & 104.2 & 84.7 & 92.3 & 82.6 \\
1936 & 113.4 & 93.3 & 80.6 & 61.7 & 109.9 & 94.1 & 94.9 & 81.0 \\
1937 & 120.8 & 101.8 & 89.1 & 76.8 & 110.0 & $n .9$. & n.a. & n.a. \\
1938 & 121.4 & $(81.4)$ & $(84.9)$ & $(70.9)$ & 106.9 & n.a. & n.a. & n.a. \\
& & & & & & & & \\
\hline & 100.0 & 100.0 & 100.0 & 100.0 & 100.0 & 100.0 & 100.0 & 100.0 \\
1973 & 106.7 & 100.4 & 95.8 & 126.4 & 101.6 & 101.7 & 97.5 & 109.1 \\
1974 & 109.7 & 100.1 & 88.5 & 119.5 & 110.0 & 107.8 & 91.9 & 110.9 \\
1975 & 116.0 & 112.1 & 94.1 & 112.0 & 110.2 & 132.0 & 97.0 & 121.9 \\
1976 & 122.3 & 123.2 & 94.7 & 110.9 & 119.3 & 142.9 & 102.0 & 132.9 \\
1977 & 127.3 & 141.2 & 87.9 & 121.2 & 131.7 & 163.6 & 97.7 & 157.5 \\
1978 & 136.1 & 152.6 & 87.5 & 141.8 & 136.8 & 171.8 & 94.5 & 165.3 \\
1979 & 143.9 & 167.7 & 92.1 & 169.7 & 145.2 & 189.6 & 91.2 & 176.3 \\
1980 & 143.9 & 190.3 & 85.6 & 175.1 & 153.0 & 209.6 & 86.4 & 183.0 \\
1981 & 142.3 & 194.0 & 83.1 & 132.3 & 161.6 & 220.4 & 81.2 & 176.5 \\
1982 & 139.3 & 214.7 & 80.2 & 103.7 & 174.1 & 245.7 & 75.9 & 193.3 \\
1983 & & & & & & & &
\end{tabular}

Notes: The above indices are all weighted averages. Iatin America includes Argentina, Brazil, Chile, Colombia, Cuba and Mexico. Asia includes China, India, Indonesia, Korea and Taiwan.

Source: Maddison (1985, p.14). 
flotations. Nevertheless, policymakers themselves saw depreciation as a threat to the national credit, albeit one less serious than default.

The pre-sterling depreciations were a Latin American and Antipodean phenomenon, starting with Uruguay in April 1929 and followed in rapid succession by Argentina, Paraguay, Brazil, Australia, New Zealand, Venezuela, Bolivia and Mexico. Australia's experience is especially revealing, since both default and devaluation were resisted so strongly. ${ }^{13}$ The Alstralian economy was adversely affected by both declining wool and wheat prices and increasingly stringent Iondon credit conditions. As early as the first semester of 1929 , the Commonealth Bank had been alarmed by the decline in its sterling balances and by its inability to float new loans in tondon. But despite the rising opportunity cost of debt service, little consideration was given to the option of default, in the hope that faithful maintenance of service might permit floating new loans in London. Instead, to curb imports the banks rationed foreign exchange and increased their rates against sterling while attempting to stay within the gold points. These expedients were viewed as temporary, and their reversal was anticipated as soon as new loans could be floated. The authorities obtained additional breathing space through the passage of legislation (patterned after the British Gold Standard and Currency and Bank Notes Acts of 1925 and 1928) which concentrated Australian gold holdings in the authorities' hands. Citizens were required to exchange gold for notes, and specie exports were discouraged by specifying a minimum quantity of gold (400 ounces fine) which could 
be obtained on demand. Hence there was additional scope for depreciation without destroying the gold standard facade.

To strengthen the trade balance and stave off depreciation, Australia adopted no fewer than seven new tariff schedules between April and December 1930. Exports were promoted by a "Grow More Wheat Campaign" and by bounties or bonuses for wine-making and gold mining. Ultimately, these efforts proved inadequate due to deteriorating world market conditions and to resistance within Labour circles to further deflationary policies. When in December 1930 a political impasse over the budget deficit threatened to unleash a wave of capital flight, those in banking circles who viewed devaluation as damaging to Australian credit acceded to the others who insisted that devaluation would be acknowledged instead as a beneficial step "towards recognition of the true state of affairs". 14 In January the currency was depreciated substantially, at which point it held until sterling's devaluation the following September. The authorities continued to hope that additional borrowing on the London market might prove possible; hence little serious consideration was given to the alternative of default except by Labour heretics such as Jack Lang in New South Wales.

\section{Debt Default}

Even after suspending convertibility, many countries found it difficult or impossible to maintain service on their external debt. 15 The debt crisis that followed can be characterized as falling into three phases. 16 The first, spanning calendar year 1931, is dominated by Latin American defaults. During the second, from January 1932 through June 1933, default spread to Southern and 
Eastern Europe. The third, whose opening coincided with the Monetary and Economic Conference of 1933, was dominated by Germany's reduction of service on its foreign debt.

Macroeconomic events, rather than disturbances Iimited to financial markets, played a leading role in the onset of the debt crisis. The Great Depression affected the ability of governments to generate both the tax revenues needed to service debt and the foreign exchange required to transfer revenues abroad. PIummeting economic activity and rising unemployment increased budgetary expenditures at the same time revenues fell. The decline in export values and volumes led to a rapid contraction of foreign exchange earnings (see Table 4). In much the same manner that an isolated bank failure can be infectious given depositors' incomplete information about the solvency of other banks, defaults by a few countries caused investors to revise their expectations for continued debt service by others. International lending all but evaporated following Bolivia's January 1931 default, and with the collapse of lending, the incentive to keep debt service current was further reduces. 17

The Latin American defaults that dominated the first phase of the crisis exhibited common features. Typically they resulted from the interaction of declining primary-commodity prices with government budget deficits (due both to expenditures on nonproductive projects and to the macroeconomic slump).18 Debt crisis and domestic political instability interacted in a vicious circle: political instability hindered attempts to achieve fiscal reform, while the crisis environment and the draconian policies 
adopted to redress the debt and budget problems threatened to undermine the most stable of governments. Although Bolivia's default was in large part a function of a 40 per cent fall in the dollar price of tin, a long history of budgetary mismanagement culminating in the government's overthrow also played a role, as the British consul had recognised fully three months hefore default: "The unlimited depredations on the state coffers by the late head of the country and his minions have left the country bled white, and there are no resources left on which to fall back. In fact there is every prospect that Bolivia will be obliged to default on her obligations in connection with foreign loans falling due in December."19

In Peru, as in Bolivia, the onset of the Depression exacerbated political unrest which culminated in revolution. While Peru's new government put a stop to what the British consul described as the previous administration's "reckless squandering" of funds, it was still forced to halt debt service in March 1931 on the grounds that the Treasury was bare of funds.20 Chile, which also experienced revolution and suffered greatly from the decline in nitrate and copper prices, defaulted four months later. Brazil, hit by a disastrous fall in coffee prices and similarly undergoing revolution, defaulted in october.

Default spread to Europe one year to the day after its appearance in Latin America. Compared with the Latin American republics, most Central and East European countries had suffered less from the collapse of primary-commodity prices (due to greater export diversification) and had pursued more austere budgetary 
policies. They were hesitant to interrupt service on the grounds that much of their debt had been arranged under League of Nations auspices. Nonetheless, Hungary's default in January 1932 was followed in rapid succession by those of Greece, Bulgaria and Yugoslavia.

The final phase of the crisis was ushered in by Germany's default. The ferman authorities had previously limited the transfer of funds to extinguish maturing loans but refrained from interfering with interest transfers. As in Latin America, default was associated with political upheaval. One of the first steps of the National Socialist Party upon taking power in 1933 was to convene a conference of bondholders' representatives with the intention of rescheduling the debt. Arrangements were made to transfer a share of accrued debt service into foreign currency, to issue scrip in place of the rest, and to convert maturing coupons into funding bonds. With few exceptions, the dollar obligations of German states, municipalities and corporations were brought under the control of the Reichsbank's Conversion Office.

Strikingly, debt default had limited repercussions in the foreign exchange market. The currencies of most defaulting latin American countries had already depreciated, while the currencies of the major European debtors were under exchange control. Moreover, in contrast to the 1980s, the deterioration of long-term foreign assets posed no direct threat to the banking systems of the creditor countries. Iinks from debt default to bank failures were broken because foreign lending took place not through bank loans but through the issue of bonds, few of which were held by banks in the 
creditor countries. Banks might participate in the syndicate which organized the loan and serve as purchasers of last resort if the market failed to take up the entire issue. But even in such instances, banks could resell their share of the issue once bondmarket conditions improved.

Commercial banks also purchased foreign bonds as investments, although information on the extent of this practice is sketchy and incomplete. For the United States, the Comptroller of the Currency provided only aggregated information on the foreign bond holdings of National Banks. According to these data, foreign bonds accounted for but a small share, on the order of 7.5 per cent, of the bond holdings of National Banks, and bonds for less than a third of total assets. The Comptroller provided no information which might be used to estimate what share of these foreign bonds were subject to default risk. But unlike the Comptroller, who listed foreign bonds only as a group, the Vermont Bank Commissioner in 1930 reported the book value of the individual foreign bonds held by each statechartered bank and trust company. 21 Table 5 lists foreign government bonds held by mutual savings banks, trust companies and savings and loan associations in Vermont on 30 June 1930. Ex post, and perhaps also ex ante given the relatively small discounts from par, most of these bonds appear to have been subject to relatively little default risk. Of the 58 banks under the commissioner's supervision, one closed its doors in 1930, but due to a bad domestic loan rather than foreign bonds, of which the bank in question in fact held none. While foreign bonds accounted for a larger share of the portfolios of the banks of certain other states, it is hard to 
Forelgn Govermment Bonds Held by

Vermont Mutual Savings Banks and Trust Campanies

June 30,1930

National Debt

Dominion of Canada

Govermment of Argentina

Govermment of Newfoundland

Kingdom of Belgium

Kingdom of Dermark

Kingdom of Norway

Kingdom of Sweden

Republic of Chile

Republic of France

Republic of Uruguay

United Kingdom of Great Britain and Ireland

United Kingdom of Great Britain and Northern

Ireland
Book Value

$\$ 453,306.00$ $276,612.50$ $295,559.46$

$1,083,219.00$

$1,208,504.12$

$896,312.38$

4,198.00

$751,074.84$

$53,885.00$

$437,179.25$

$159,205.00$

$22,687.50$

Provincial Debt

Province of Alberta

Province of British Columbia

$317,011.52$

$195,125.00$

Province of Manitoba

$69,318.80$

Province of New Brunswick

$19,587.50$

Province of Nova Scotia

$14,400.00$

Province of Ontario

$913,371.43$

Province of Quebec

$48,271.00$

Province of Saskatchewan

$244,821.25$

Miscellaneous Canadian bonds

$927,245.44$

Source: $\quad$ State of Vermont (1930). 
see how foreign defaults alone could have posed a serious threat to the US banking system. It is likely that the same conclusion holds for the UK and other creditor countries.

A more serious threat was posed by the liquidation of foreign bank deposits. The exception to the debtor-country rule of giving priority to debt over convertibility concerned the treatment of short-term credits. These credits typically originated in connection with commercial transactions. As the Depression deepened, not only did credits to finance international transactions become redundant, but financial uncertainty induced foreigners to convert them into domestic currency. Commercial banks in the indebted regions consequently experienced sudden withdrawals of foreign balances. Their governments responded with exchange control and prohibitions on the repatriation of short-term capital. For example, when in october 1931 Argentina experienced accelerating depreciation, it imposed exchange control and froze short-term liabilities, which were owed predominantly to British creditors. After nineteen months an agreement was reached with Britain, under the provisions of which a long-term loan was floated to provide funds to transfer the frozen accounts. What is noteworthy is that Argentina, at the same time as it faithfully maintained service on its long-term debt, did not hesitate to restrict foreign access to short-term liabilities. The difference is attributable to the higher costs of leaving short-term debt unfettered, given its volatility in response to changes in anticipated returns, and the greater benefits of leaving service on long-term debt uninterrupted in the hope that additional long-term borrowing might again prove 
possible for the creditworthy.22

Short-term Credits, Bank Failures and Intervention

The preceding discussion has focused on links between exchange-rate convertibility and debt. A noteworthy aspect of Argentine experience is the absence of the next link in the chain, from debt and exchange rates to bank failures. While, as noted above, sovereign default was not a major source of instability of creditor-country banking systems, the same was not always true of debtor-country banks. Short-term debt was an important item on the liability side of many debtor-country-bank balance sheets, even if, due to their greater size, it represented a small item on the asset side of creditor-country-bank balance sheets.

In particular, foreign attempts to repatriate short-term credits in the summer of 1931 posed major threats to the solvency of the Austrian and German banking systems. Serious difficulties surfaced in Europe with the run on the Austrian Credit-Anstalt in May 1931. The problems of the Credit-Anstalt, while largely of domestic origin, were greatly complicated by its dependence on foreign credits. Austria had been the second Furopean state (after Sweden) to stabilize its currency, and the early date of its stabilization in conjunction with League of Nations sponsorship promoted a sizeable inflow of foreign funds to the banking system. The Credit-Anstalt had participated fully in the amalgamation movement of the 1920s, absorbing the Bodenkreditanstalt and its portfolio of dubious industrial loans, and in 1929, when the market value of these loans declined precipitously, this amalgamation returned to haunt it. 23 Regulations forced the credit-Anstalt to 
publish its 1930 balance sheet on 11 May 1931, revealing that it had lost more than half its capital, the criterion according to which it was officially declared insolvent. This announcement provoked large-scale withdrawals by domestic and foreign creditors.24 A $\$ 14$ million credit obtained through the Bank for International settlements was exhausted within five days, and a subsequent loan from the Bank of England lasted little longer. The government's next step was to freeze foreign balances, and on 16 June 1931 foreign creditors agreed to a two-year suspension of transfers provided that the Austrian Government guaranteed the debts. A second standstill between other Austrian banks and their creditors followed. Although this freeze of foreign transfers did not put a halt to domestic withdrawals, which continued through 1931, the Credit-Anstalt's doors remained open by virtue of large rediscounts with the National Bank. This aspect of Austrian experience suggests a lesson common to Europe and Latin America: shocks with the potential to destabilize the banking system did not lead to generalized collapse because central banks acted in lenderof-last-resort capacity and simply did not permit this to occur. 25

The Austrian run alerted creditors to the precarious position of other countries dependent upon short-term credits from abroad, notably Germany and the successor states of Eastern Furope. Table 6 indicates the extent of short-term foreign indebtedness of the German banking system. Even had German banks not shared many of the weaknesses of their Austrian counterparts, they would have suffered withdrawals given depositors' incomplete information about their position and the signal provided by the credit-Anstalt 
Short-term Indebtedness of Selected Buropean Countries

(millions of US dollars)

\begin{tabular}{|c|c|c|c|c|c|c|c|c|}
\hline Country & Date & $\begin{array}{l}\text { Central } \\
\text { Govern- } \\
\text { ment }\end{array}$ & $\begin{array}{l}\text { Local } \\
\text { autho- } \\
\text { rities }\end{array}$ & $\begin{array}{c}\text { Centra } \\
\text { bank }\end{array}$ & $\begin{array}{l}\text { Other } \\
\text { banks }\end{array}$ & $\begin{array}{l}\text { Other } \\
\text { debtors }\end{array}$ & Total & $\begin{array}{l}\text { Gross } \\
\text { Foreign } \\
\text { Debt }\end{array}$ \\
\hline Austria & IX 1932 & 14.1 & 0.3 & $c$ & & 19.4 & 155.7 & $583^{*}$ \\
\hline Hungary & XI 1931 & 42.8 & 21.8 & 25.3 & 106.7 & 124.0 & 320.3 & $695^{*}$ \\
\hline Bulgaria & XII 1931 & 4.2 & 3.4 & 1.1 & 10.3 & 23.4 & 42.4 & n.a. \\
\hline Poland & XII 1931 & 0.4 & - & $c$ & .1 & 27.9 & 33.4 & $1130^{x}$ \\
\hline Romania & 1932 & & & 13.5 & 23.7 & 41.9 & 79.1 & 965 \\
\hline Dermark & XII 1932 & & - & & & 36.2 & 61.2 & 361 \\
\hline Finland & XII 1932 & 7.5 & 1.4 & 4.7 & 24.4 & 17.5 & 55.5 & 296 \\
\hline Norway & I 1933 & & 2.2 & & 19.7 & 106.9 & 128.8 & 373 \\
\hline Germany & IX 1932 & & 0 & 193.6 & 918.4 & 963.3 & $2,223 \cdot 3$ & 4670 \\
\hline
\end{tabular}

Note: Asterisk denotes 1930 value; n.a. denotes not available. Gross foreign indebtedness for Poland includes direct foreign investment.

Sources: League of Nations $(1933,1937,1938)$ and Royal Institute (1937). 
crisis.26 The Darmstadter Bank, which failed on 13 July 1931, had invested heavily in textiles in general and in the bankrupt Nordwolle firm in particular, as well as in the nearly insolvent municipalities of the Rhine-Ruhr region. Foreign deposits figured prominently on the liability side of its balance sheet. Between mid-1930 and July 1931, German statistics show withdrawals of 2.5 to 3 RM billion in short-term foreign credits, or roughly half of the gross short-term liabilities of the 28 most important German banks.

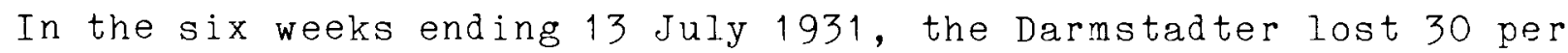
cent of its deposits, culminating in a run that forced the closure of all German financial institutions. As the price of state support, the Reich fused the Darmstadter with another bank and replaced its board of directors. To prevent capital flight, the Reichsbank was given a monopoly of transactions in foreign exchange. Under the provisions of an agreement coming into force in september, transfers of short-term debt were suspended for six months and then for a year starting February 1932. Nonperforming assets were written down and new capital was secured with the aid of the Treasury and, indirectly, the Reichsbank.

Next to Austria and Germany, Hungary was most seriously affected by the liquidation of short-term credits. In the Hungarian case, first the credit-Anstalt disclosures led to a withdrawal of foreign credits, and then the German banking crisis precipitated a domestic run. The government declared a three-day bank holiday, limited withdrawals and instituted exchange control. Together with heavy rediscounts by the Central Bank, these measures prevented widespread failures. The experience of Romania, the next largest 
short-term external debtor, differed in that official exchange control was only introduced in May 1932, and in its absence rediscounts with the National Bank were provided even more liberally.

The role of the lender of last resort in containing bank failures is evident in latin America as well. As noted above, Argentina escaped bank failures because of the substantial rediscount and other credits extended to commercial banks by the Banco de la Nacion: rediscounts rose from 80 million pesos at the end of 1928 to 160 million pesos in April 1931, while advances to banks against government bills rose from 190 to 250 million pesos. Where rediscounts were less liberally provided, instability was greater: in Peru, for example, the Banco del Peru y Londres suspended payments in October 1930, occasioning a banking moratorium lasting through the end of the year. The authorities responded by encouraging amalgamations and, after 1931 , by increasing rediscounts.

The United Kingdom and the United States are the two prominent exceptions to this pattern, the UK because the banking system was not threatened, the US because of the extent to which it was. The relationship between the prices of industrial and bank stocks shown in Table 7 can be taken to indicate the condition of national banking systems relative to the condition of national economies. The table confirms that the British banking system weathered the crisis exceptionally well while the American banking system suffered profoundy. 
Indices of Prices of Bank Shares and Incustrial Shares, 1930-1933

$$
(1929=100)
$$

VI XII VI XII VI XII VI $X I I$

$\begin{array}{llllllll}1930 & 1930 & 1931 & 1931 & 1932 & 1932 & 1933 & 1933\end{array}$

\begin{tabular}{|c|c|c|c|c|c|c|c|c|c|}
\hline Belgium & $\begin{array}{l}\text { Banks } \\
\text { Industrial }\end{array}$ & $\begin{array}{l}66 \\
72\end{array}$ & $\begin{array}{l}55 \\
55\end{array}$ & $\begin{array}{l}47 \\
52\end{array}$ & $\begin{array}{l}36 \\
35\end{array}$ & $\begin{array}{l}30 \\
29\end{array}$ & $\begin{array}{l}35 \\
36\end{array}$ & $\begin{array}{l}35 \\
35\end{array}$ & $\begin{array}{l}35 \\
29\end{array}$ \\
\hline Canada & $\begin{array}{l}\text { Banks } \\
\text { Industrial }\end{array}$ & $\begin{array}{l}85 \\
62\end{array}$ & $\begin{array}{l}80 \\
45\end{array}$ & $\begin{array}{l}72 \\
34\end{array}$ & $\begin{array}{l}69 \\
28\end{array}$ & $\begin{array}{l}45 \\
18\end{array}$ & $\begin{array}{l}50 \\
22\end{array}$ & $\begin{array}{l}54 \\
39\end{array}$ & $\begin{array}{l}47 \\
40\end{array}$ \\
\hline Denmark & $\begin{array}{l}\text { Banks } \\
\text { Industrial }\end{array}$ & $\begin{array}{l}93 \\
92\end{array}$ & $\begin{array}{l}96 \\
90\end{array}$ & $\begin{array}{l}92 \\
88\end{array}$ & $\begin{array}{l}75 \\
81\end{array}$ & $\begin{array}{l}70 \\
71\end{array}$ & $\begin{array}{l}78 \\
74\end{array}$ & $\begin{array}{l}91 \\
85\end{array}$ & $\begin{array}{r}101 \\
90\end{array}$ \\
\hline France & $\begin{array}{l}\text { Banks } \\
\text { Industrial }\end{array}$ & $\begin{array}{l}89 \\
85\end{array}$ & $\begin{array}{l}76 \\
66\end{array}$ & $\begin{array}{l}73 \\
62\end{array}$ & $\begin{array}{l}46 \\
41\end{array}$ & $\begin{array}{l}47 \\
44\end{array}$ & $\begin{array}{l}54 \\
47\end{array}$ & $\begin{array}{l}52 \\
48\end{array}$ & $\begin{array}{l}50 \\
43\end{array}$ \\
\hline Germany & $\begin{array}{l}\text { Banks } \\
\text { Industrial }\end{array}$ & $\begin{array}{l}88 \\
86\end{array}$ & $\begin{array}{l}74 \\
62\end{array}$ & $\begin{array}{l}66 \\
53\end{array}$ & $\begin{array}{l}\text { n.a. } \\
\text { n.a. }\end{array}$ & $\begin{array}{l}35 \\
36\end{array}$ & $\begin{array}{l}35 \\
47\end{array}$ & $\begin{array}{l}37 \\
56\end{array}$ & $\ddot{52}$ \\
\hline Netherlands & $\begin{array}{l}\text { Banks } \\
\text { Industrial }\end{array}$ & $\begin{array}{l}94 \\
73\end{array}$ & $\begin{array}{l}83 \\
51\end{array}$ & $\begin{array}{l}82 \\
43\end{array}$ & $\begin{array}{l}56 \\
30\end{array}$ & $\begin{array}{l}47 \\
21\end{array}$ & $\begin{array}{l}57 \\
30\end{array}$ & $\begin{array}{l}66 \\
33\end{array}$ & $\begin{array}{l}58 \\
32\end{array}$ \\
\hline $\mathrm{U} . \mathrm{K} .^{2}$ & $\begin{array}{l}\text { Banks }{ }^{3} \\
\text { Industrial }\end{array}$ & $\begin{array}{l}92 \\
75\end{array}$ & $\begin{array}{l}97 \\
64\end{array}$ & $\begin{array}{l}89 \\
56\end{array}$ & $\begin{array}{l}68 \\
49\end{array}$ & $\begin{array}{l}82 \\
45\end{array}$ & $\begin{array}{l}96 \\
57\end{array}$ & $\begin{array}{l}96 \\
63\end{array}$ & $\begin{array}{r}104 \\
70\end{array}$ \\
\hline U.S.A. & $\begin{array}{l}\text { Banks }{ }^{4} \\
\text { Industrial }\end{array}$ & $\begin{array}{l}67 \\
77\end{array}$ & $\begin{array}{l}43 \\
55\end{array}$ & $\begin{array}{l}38 \\
47\end{array}$ & $\begin{array}{l}21 \\
29\end{array}$ & $\begin{array}{l}14 \\
18\end{array}$ & $\begin{array}{l}23 \\
24\end{array}$ & $\begin{array}{l}21 \\
42\end{array}$ & $\begin{array}{l}15 \\
43\end{array}$ \\
\hline Sweden & $\begin{array}{l}\text { Banks } \\
\text { Industrial }\end{array}$ & $\begin{array}{r}104 \\
90\end{array}$ & $\begin{array}{r}101 \\
80\end{array}$ & $\begin{array}{l}93 \\
73\end{array}$ & $\begin{array}{l}70 \\
48\end{array}$ & $\begin{array}{l}50 \\
31\end{array}$ & $\begin{array}{l}53 \\
35\end{array}$ & $\begin{array}{l}53 \\
39\end{array}$ & $\begin{array}{l}58 \\
39\end{array}$ \\
\hline Switzerland & $\begin{array}{l}\text { Banks } \\
\text { Industrial }\end{array}$ & $\begin{array}{l}98 \\
89\end{array}$ & $\begin{array}{l}96 \\
75\end{array}$ & $\begin{array}{l}97 \\
77\end{array}$ & $\begin{array}{l}61 \\
50\end{array}$ & $\begin{array}{l}49 \\
45\end{array}$ & $\begin{array}{l}61 \\
54\end{array}$ & $\begin{array}{l}60 \\
68\end{array}$ & $\begin{array}{l}60 \\
66\end{array}$ \\
\hline
\end{tabular}

Notes: $1 . \quad$ No quotation.

2. $31 . X I I .1928=100$.

3. Banks and discount companies.

4. New York bank shares.

Source: League of Nations (1934). 
In the British case, external credits again play a role, but in a rather different fashion. 27 The extent of Britain's short-term liabilities, while known to experts, was heralded by the publication of the Macmillan Committee Report in the summer of 1931. Combined with uncertainty about the defensibility of the sterling parity due to a budgetary impasse and British creditors' inability to withdraw funds from Austria and Germany, it led to a run on the pound which forced Britain from the gold standard in September. But since the discount market and the Governinent, not only the banks, relied on foreign funds, and since the run took the form mainly of sales of foreign-owned Treasury bills and withdrawals of credits previously granted to the discount market, it posed little threat to the banking system. In the three months ending september 1931, total deposits of the ten London clearing banks fell by $£ 70 \mathrm{million}$, not an insignificant amount but small in comparison with experiences on the Continent.

Even in the United States, where agricultural foreclosure and industrial insolvency are typically emphasized as explanations for bank failure, foreign credits played a role. Signs of widespread financial distress surfaced in June 1931, when foreigners reduced their holdings of dollar acceptances and transferred their deposits from commercial to reserve banks. With Britain's abandonment of the gold standard these movements accelerated. In part these withdrawals of foreign deposits reflected the imposition of exchange control abroad, which rendered the United States one of the few remaining sources of liquidity for foreigners scrambling for funds. 
Foreign withdrawals were particularly damaging to the banking system because they reinforced domestic sources of weakness. In the course of the 1920s, US commercial banks had greatly augmented the security and real estate components of their portfolios. 28 collapse of the security and mortgage markets therefore rendered their asset position especially vulnerable. Real estate loans, which tended to be geographically undiversified due to restrictions on branch banking, increased the vulnerability of thousands of small unit banks to sector-specific shocks. Their desperate attempts to restore liquidity induced them to call in open-market loans and sell securities. Similar responses occurred in other countries although, as Table 8 makes clear, the liquidity position of US banks had eroded particularly dramatically over preceding years.29 In response, Us banks restricted loans, giving rise to widespread complaints among manufacturing firms about a shortage of credit. The scramble for liquidity reinforced the collapse of the bond market. The prices of domestic bonds fell so dramatically that by June 1932, when the rate on 3-month acceptances had fallen below one per cent, domestic industrial bonds werequoted on an 11 per cent yield basis and second grade rails yielded 19 per cent. While some component of these yields indicates the magnitude of the risk premium, their high level may also reflect distress sales and therefore the generalized effects of the financial crisis, which severely disrupted the domestic bond market's ability efficiently to allocate funds among competing uses in much the same manner that the collapse of the market in foreign bonds reduced international investment to a trickle. 30 
TABLE 8

Bank Cash Resources as Percentage of Total Deposits (end of June)

\begin{tabular}{|c|c|c|c|c|}
\hline & 1929 & 1930 & 1931 & 1932 \\
\hline France & 7.4 & 9.7 & 13.9 & 33.6 \\
\hline Swltzerland & n.a. & n.a. & 11.3 & 22.9 \\
\hline United Kingdom & $11 \cdot 3$ & 11.5 & 11.7 & 11.5 \\
\hline United States & $7 \cdot 3$ & 7.4 & 7.6 & 8.2 \\
\hline Italy & 6.9 & 6.6 & 6.2 & 5.9 \\
\hline Germany & 3.1 & 2.7 & 3.6 & 3.4 \\
\hline Poland & 8.5 & 8.8 & $10 \cdot 7$ & 9.0 \\
\hline Sweden & 2.1 & 2.3 & 2.1 & 3.8 \\
\hline Czechoslovakia & 6.7 & $7 \cdot 3$ & $7 \cdot 2$ & 7.4 \\
\hline South Africa & $10 \cdot 3$ & 10.0 & 9.1 & 10.1 \\
\hline Argentina & $17 \cdot 9$ & 14.2 & 13.4 & 17.5 \\
\hline Australia & 15.6 & 13.4 & 19.2 & 17.8 \\
\hline Canada & $13 \cdot 3$ & $12 \cdot 1$ & 10.9 & 12.2 \\
\hline Chile & 14.4 & 12.6 & 9.5 & 26.4 \\
\hline Japan & 9.1 & 9.0 & 10.1 & 9.8 \\
\hline New Zealand & 12.3 & 13.0 & 13.7 & 11.5 \\
\hline
\end{tabular}

Note: n.a. signifies not available.

Source: League of Nations (1933). 
Although the literature on the American Depression emphasizes the two waves of bank failures in the late autumn of 1930 and early spring of 1933, in fact failures continued throughout. In october 1931, for example, 522 banks with deposits amounting to $\$ 470$ million were forced to suspend payments, and in the 12 months ending in June 1932, 2429 US banks failed. Again, the pattern of failure mirrors the actions of the authorities. In the spring of 1932 the incidence of bank failures declined as the Federal Reserve expanded credit through rediscounts and open market operations, but this expansionary initiative was reversed soon thereafter, permitting a resurgence of commercial bank insolvencies. 31

The US case provides a graphic illustration of linkages running from bank failures to other markets and to the macroeconomy. Although it is still disputed whether monetary stringency, much of which resulted from bank failures, was a factor in the onset of the Great Depression, it is widely agreed that these monetary factors were central to its singular depth and long duration. The inability of the Federal Reserve to prevent widespread bank failures, along with its inability to interrupt the linkages running back from bank failures to financial markets and to the macroeconomy, is a central explanation for the severity of the crisis in the United States. Thus, one reason for the exceptional depth of the Great Depression in the US was that policy was used less effectively than in other countries to prevent the transformation of financial market disturbances into a generalized financial crisis. 


\section{A. The Periods Compared}

A summary of the apparent similarities and differences between our two periods will be useful background for our analysis. In the 1930s as in the 1980s, illiquidity was not confined to any one country or region. In neither instance can the problems of debtor countries be attributed exclusively to domestic causes - external shocks from the world economy were transmitted through sharp rises in real interest rates and falls in commodity prices and the economic activity of industrial countries. The burden of reparations inhibited expansion just as the burden of debt service does in many countries today (McNeil, 1986).

There can be no exact dating of recent troubles in international financial markets, nor a fortiori a precise correspondence between 1929 and 1979. Nevertheless, to take 1979 as the beginning of the contemporary period of interest is not merely a convenient metaphor. Admittedly, one cannot identify at that point a classical panic, preceded by "mania", then "distress", and followed by sharp, generalized price falls (Kindleberger, 1978). But conditions in the world economy and financial system clearly did deteriorate from the second oil shock to the Mexican collapse of August 1982, which marks the onset of the "debt crisis" in popular consciousness.

Any simple analogy with 1932, however, would be equally inappropriate. For just as the contemporary debt crisis began the 
American economy entered a period of strong expansion which compensated, until recently, for the drag on world economic activity caused by the overhang of LDC debt and restrictive macroeconomic adjustment policies adopted to deal with it.

We have seen many debt reschedulings but not widespread, extended interruptions of service and amortization on the scale of the 1930s; even the deterioration of relations between Peru and the IMF in August 1986 is not strictly comparable to the defaults which began in January 1931. There have been wide swings in nominal and real exchange rates but no significant currency collapses, nor any resort to inconvertibility or new exchange controls to protect any major currency. Real interest rates rose to historically exceptional heights, but there was no worldwide dramatic fall of investment. Large government budget deficits in industrialized countries have in most cases (with a major exception!) been brought under control, with many crisis budgets but no collapse of government finances. There have been large trade imbalances and repeated threats of a plunge into overt protectionism, but in practice we have seen only the gradual accretion of non-tariff barriers to trade. Failures of individual financial institutions have been isolated, without generalized runs or significant contractions in the credit base. One authority judges that the crisis was worst in 1982-84 and is now over (Kindleberger, 1986). We are less sanguine, and we stress in particular the need for continued and improved international policy coordination in providing the regulatory and macroeconomic environments necessary to prevent financial crisis. But despite greater interdependence in 
the world economy - and partly in response to it - institutional

change and economic policies have tended to break, block or attenuate the linkages of our Figure 1. A further difference from the $1930 \mathrm{~s}$ is more difficult to analyze: the growing assertiveness of the United States and the political consensus among the major industrialized countries in dealing with international debt problems (Diaz-Alejandro, 1984; Portes, 1986). It has been more difficult for any single debtor country, particularly in Latin America, to break ranks, and the cohesion of the creditors' cartel contrasts sharply with feeble efforts at coordination among debtors.

As noted, in both the 1930s and 1980s, the preceding decade had been marked by major changes in the structure and management of the international political economy. Before World War I, the United Kingdom played the pivotal role in the worla economy, using its investment income to run a trade deficit that allowed other countries to pursue export-led growth. When world War I and its aftermath cut that income, the United States assumed the financial role of the world's leading creditor without taking on the corresponding responsibility of running an import surplus with open markets, thus leaving a structural weakness in the system. Now the transition from the United States to Japan as dominant lender is similarly occurring without a shift by Japan into import surplus (though in this case, with little immediate weakening of American political dominance).

Yet differences between the periods preclude simple generalizations. In the 1970s, the banks did not act merely as intermediaries in placing LDC bond issues among many dispersed 
bondholders, but rather took on very large direct exposure, with corresponding risk to themselves and the financial system. 32

Although there was significant cross-border lending among banks in the earlier period, the density of international interbank relationships now is incomparably greater. For both reasons, creditors have been much better organized in the 1980s than in the 1930s, a change that has favored rescheduling rather than default. 33 But banks appear to have paid no more attention to sovereign risk in the lending of the 1970s than in that of the 1920s. And they lent at considerably shorter maturities than those of the $1920 \mathrm{~s}$ bond issues.

An institutional difference of considerable practical importance is the International Monetary Fund. To some extent, the IMF acts as international lender of last resort, while also serving the capital market in a signalling capacity, providing information on domestic adjustment programs and helping to differentiate among borrowers. There are also stronger domestic lenders of last resort (new, in some countries), with more extensive supervisory and regulatory roles now than fifty years ago despite recent moves towards deregulation; and there is deposit insurance in many countries. The macroeconomic background differs as well, with much greater experience of stabilization policies, a system of floating exchange rates in existence for over a decade, and extended international discussion of domestic macroeconomic policies in economic summits, the OECD and the EEC. Finally, there is greater political stability in relations among the industrialized creditor countries, and perhaps greater internal political stability in the LDC debtors. 


\section{B. The Environment}

Our description of the international financial environment begins with the breakdown of the Bretton Woods payments settlement and exchange rate systems in the early 1970s. A detailed history is not needed here. But the major events have brought deep structural change closely analogous to that of the 1920s, in the exchange rate system, in international lending, and in financial institutions.

The changes in the exchange rate system during 1971-73, while in the opposite direction to those of the mid-1920s, were equally profound and far-reaching. 34 official convertibility of dollars into gold was abandoned in August 1971, and the adjustable-peg exchange-rate mechanism gave way to unrestricted floating in March 1973. The "reform" negotiations of the 620 and its successors could not reconstruct or replace the constraints which Bretton woods had imposed on the autonomy of national monetary authorities. The new freedoms and powers were de jure rather than de facto, however, as policy-makers, academic analysts and the markets soon discovered. The same capital mobility which made the old exchange rate system untenable also made true autonomy infeasible.

Among the many complementary explanations for the breakdown of the Bretton Woods exchange rate system, we stress capital mobility as fundamental. So did the architects of the system and their predecessors. Nurkse (1944) identified "disequilibrating" capital flows as a major cause of the disturbances of the interwar period. Keynes insisted that controls over capital movements be an essential component of the postwar monetary order, and the Bretton Woods Agreement made no provision for convertibility for capital account 
transactions. But the progressive relaxation of exchange controls and convertibility restrictions starting in the early 1950s did extend to capital flows. Their volume and speed grew dramatically as a function of technological innovation and profit opportunities. Since the authorities were unwilling to make the Bretton Woods exchange rate system their sole policy target, official convertibility and the adjustable peg could not withstand the pressures arising from the growing sophistication, scope and integration of international capital markets. This process has of course continued, and we return to it below.

Currency convertibility and the international institutions established at Bretton Woods survive. Moreover, the political relationship between France and Germany in the context of the European Community gave rise in 1979 to the European Monetary System, with its exchange rate mechanism providing a "zone of [relative] monetary stability" among most of the FC currencies. 35 Even outside the exchange-market intervention in the EMs, the major currencies have not floated freely since 1973. Exchange rates have been regarded as important indicators or even targets for monetary policy, leading to intervention, whether unsterilized or sterilized. 36 This raises the question whether, by the end of the 1970s, the resulting exchange rate system was well-suited to absorb major macroeconomic and financial shocks, or whether the system propagated or even magnified such disorders, which might then be transmitted to capital markets and the financial system (Iinkages II and $V$ in Figure 1).

The explosive growth of international lending in the 1970 s is 
also familiar to contemporary observers.37 Analysts still differ, however, in the importance they assign to supply and demand factors affecting international lending during the period. Econometric explanations of its volume and price perform no better than econometric models of exchange rate behaviour. It is clear that the 1970 s saw a striking, unexpected growth of liability financing of balance-of-payments deficits under little apparent constraint for most countries; and that aggregate liquidity in the world economy was correspondingly demand-determined.

The process of institutional change in the banking systen during the 1970 s was also driven by the powerful forces of internationalization and the technological change which stimulated and facilitated it. The pace of internationalization may have slowed somewhat in the past five years. 38 mis has not eased the regulatory authorities' task in keeping abreast of these changes. The problems of the banking system in 1974-75, from spectacular bank failures like Franklin National and Herstatt to many lesser difficulties, were surmounted.39 But the Basle concordat of 1975 was just the beginning of a much more active, continuous process of consultation among central banks, in good part through the continuing work of the Cooke Committee. This internationalized prudential supervision also forms an important part of the environment in which the events of the past several years have transpired. 


\section{Disturbances and their Management}

The two major sources of recent instability are those of fifty years earlier: disturbances in the foreign exchange market and sovereign debt.

Major exchange rate swings and misalignments, as well as sharp deterioration in the debt-servicing capacity of individual countries, have undoubtedly threatened domestic financial institutions and the international financial system. There have been isolated, individual cases of bank failures, some quite spectacular, at least judging by the reaction of the media. Banco Ambrosiano, Johnson Matthey and Continental Illinois offered highgrade material to all from sensational journalists to sober academics. The scandals and political fallout were greater in Rome and London than in Chicago, but financially the most serious was Continental Illinois, then the 20 th largest U.S. bank and a major participant in the international interbank market. Despite a classic run by foreign holders of its CDs, the bank was saved by the regulators (without bailing out its officers and shareholders), and there were no spread effects nor generalized financial crisis resembling the 1930s.

Stresses in foreign exchange markets, international lending and the banking system are striking, and they suggest analogies with the interwar period. These comparisons help to explain why there has so far been no collapse like that of the 1930 s and shed light on the continuing vulnerability of the financial system. We shall therefore turn to data on the size of imbalances and shocks, on the capacity of the exchange-rate system to cope with misalignments and 
volatility, and on how the debt crisis has been managed. We then consider the linkages represented in Figure 1 and the roles of policy and institutional change in attenuating them.

\section{Exchange Rates}

The exchange rate system operating since 1973 has survived both unexpectedly high volatility and substantial misalignments without exchange-market collapse or any overall drift towards controls. 40 Central bank intervention has doubtless helped; few would argue that it has been destabilizing, though many would judge its influence to be marginal. It has certainly not eliminated short-run volatility. Nor has market learning reduced volatility as the floating-rate period has gone on. Even the EMS has had only limited effects: among the major EMS currencies, only the Deutschmark and lira experienced clear declines in overall volatility (with respect to all currencies) from 1978 to 1984.41 on most assessments, however, the EMS has succeeded in reducing volatility among the currencies participating in its exchange-rate mechanism, as one would expect.42

Yet more than a decade of learning among market participants and the authorities has apparently not delivered the supposediy stabilizing effects of speculative activity. The EMS may be interpreted as one response to this disappointment, while the rapidly developing forward and futures markets now provide ample opportunities to protect against exchange-rate instability. Recent evidence suggests, however, that these opportunities are not used fully to insulate trade, and that exchange-rate volatility does in fact have empirically significant effects on the volume of 
international trade.43 And the new markets and instruments can be used not only to hedge but also to gamble. We must therefore regard short-run volatility still as evidence of instability which might itself spread through the financial and real economies.

Even more dangerous, however, are the large exchange-rate swings and misalignments of long duration which have characterized the period since 1973. Williamson (1985, p. 17) cites maximum swings in real effective exchange rates during 1973-82 of 22 per cent for the Deutschmark, 19 per cent for the French franc, 32 per cent for the U.S. dollar, 35 per cent for the yen, and 60 per cent for the pound. His graph (reproduced as our Figure 2) is striking testimony to the magnitude of these gyrations and their extended duration. His calculations of misalignments give one measure, admittedly controversial, of the exchange-rate imbalances creating strains on other elements of the financial system. Table 9 gives these estimates of divergencies from "fundamental equilibrium exchange rates" in 1984 Q4. One need not fully accept the methodology or conclusions to judge that the misalignments are likely to have been two to three times the magnitude of those estimated by Keynes for the 1920s.

Fven in the absence of an agreed model of exchange-rate determination, there is consensus that changes in such fundamentals as the current account and purchasing power parities (or even "safe haven" effects) cannot fully explain these shifts. Nor are they solely due to inappropriate monetary policies and exchange-rate targets (as the pegs of the 1920s represent). An unbalanced mix of monetary and fiscal policies within the United States and among the 


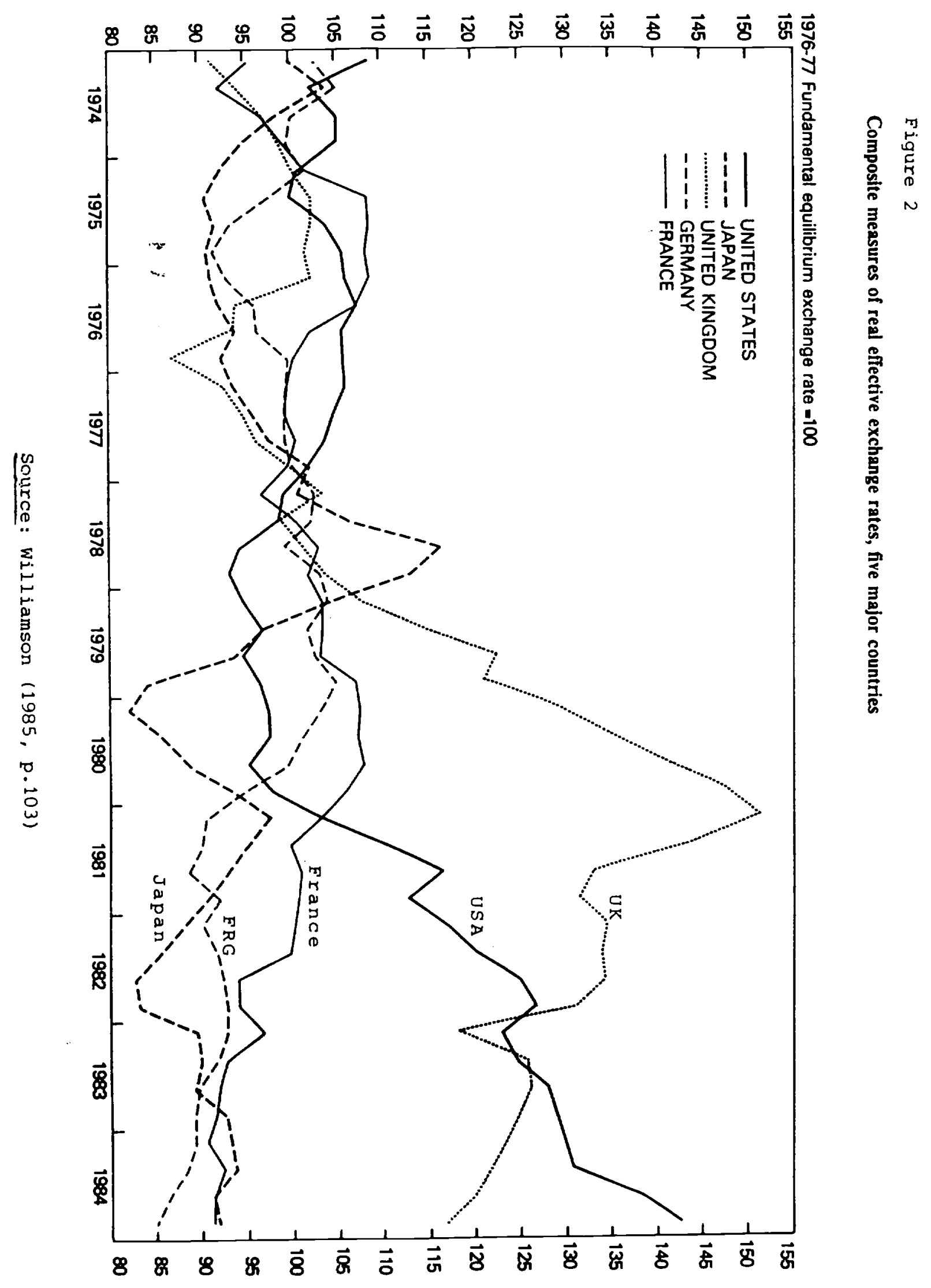


TABLE 9

Estimates of exchange-rate misaligmments, 1984 Q4

\begin{tabular}{lccc}
\hline & $\begin{array}{c}\text { Effective } \\
\text { exchange } \\
\text { rate relative } \\
\text { to estimated } \\
\text { fundamental } \\
\text { equilibrium }\end{array}$ & $\begin{array}{c}\text { Fundamental } \\
\text { equilibrium } \\
\text { rate against } \\
\text { US dollar }\end{array}$ & $\begin{array}{c}\text { Nominal } \\
\text { appreciation } \\
\text { needed } \\
\text { against } \\
\text { US dollar } \\
\text { (percentage) }\end{array}$ \\
\hline US dollar & 137 & n.a. & n.a. \\
Japanese yen & 89 & Y 198 & 24 \\
Deutschemark & 87 & DM 2.04 & 50 \\
French franc & 92 & FF 6.51 & 44 \\
Pound sterling & 107 & $\$ 1.52$ & 25 \\
\hline
\end{tabular}

n.a.: Not applicable.

Source: W1lliamson (1985, p.79). 
major industrial countries is a more comprehensive explanation, especially insofar as it underlies the wide swings in nominal and real interest rates and international interest rate differentials. Yet it is increasingly agreed that speculative "bubbles", with or without rational expectations, also played a role in accentuating recent exchange-rate swings.44 If so, then exchange rates are still highly uncertain for participants in trade and financial markets, however much they hedge.

This longer-run uncertainty may reduce trade volumes just as volatility appears to do, and direct investment may suffer as well. Large and sustained misalignments impede trade by encouraging protectionist policy responses. Since debt servicing capacity derives from trade flows, there is an indirect link from the exchange-market disturbances of the past decade to debt defaults (linkage III in Figure 1). Yet this differs from the link we identified for the earlier period, in which convertibility crises and the threat of exchange control induced withdrawals of short-term funds, which in turn could provoke default. Nor do exchange-rate misalignments appear to have threatened the banking systems in either creditor or debtor countries (linkage V). But exchange-rate uncertainty and volatility may have increased the importance of this link by offering banks new opportunities for speculation. Some have participated aggressively in these markets (often seeking to build up earnings depleted by bad loans), and some of these have not succeeded (Franklin National and Herstatt were early victims).

A more important example of linkage III can be found in the LDC debtor countries themselves. In several cases, exchange-rate 
overvaluation has led to massive capital flight by domestic residents, seriously exacerbating debt-servicing difficulties. 45 Insofar as overvaluation is a direct result of government policy, exchange-market intervention rather than post-1973 exchange-rate flexibility is the cause of the problem.

On balance, we are inclined to accept the judgment of cooper (1983) that flexible exchange rates have served more as a shock absorber than as a source of destabilizing influences in the financial system or as a link in their transmission. The misalignments which this flexibility has permitted, by removing a constraint on monetary and fiscal policies, have not themselves provoked financial crisis or exacerbated financial instability, whatever their negative effects on trade and investment. Indeed, it is the process of correcting the misalignments without the appropriate coordination of macro policy mixes which might be highly destabilizing. 46

$\underline{\text { Debt }}$

As in the 1920s, the growth and export performance of major borrowing countries in the latter half of the 1970 s gave some cause for optimism regarding the recycling process and the prospects for debt service.47 Table 10 gives data comparable with Table 2 for the earlier period. In both cases, however, the assumption that expansion would continue without major shocks proved to be false.

The problems which ensued were indeed similar. The major external shocks which hit the debtor countries were global, not country-specific. The second oil shock, the OECD recession and the industrialized countries' restrictive monetary policies created 
TABLE 10

Amual Growth Rates of Real GDP and Exports, 1975-79

\begin{tabular}{lcc} 
& GDP & $\begin{array}{c}\text { Exports } \\
\text { In US Dollars }\end{array}$ \\
\cline { 2 - 3 } Argentina & 1.1 & 27.2 \\
Brazil & 6.6 & 15.9 \\
Chile & 7.4 & $25.7^{*}$ \\
Mexico & 6.2 & $32.7^{*}$ \\
Venezuela & 4.7 & $13.1^{*}$ \\
Peru & 0.9 & $28.0^{*}$ \\
Nigeria & 1.2 & $22.5^{*}$ \\
India & 2.6 & 15.7 \\
Indonesia & 7.4 & 21.6 \\
Korea & 10.6 & 30.9 \\
Malaysia & 8.8 & 30.3 \\
Philippines & 6.6 & 18.6 \\
Egypt & n.a. & 6.9 \\
Turkey & 3.7 & 12.5 \\
Yugoslavia & 6.4 & 12.4
\end{tabular}

(*) more than 50\% increase in 1979 over previous year.

Source: International Financial Statistics 1983 Yearbook. 
serious fiscal problems in the debtor countries (aggravated by domestic mismanagement) and cut the prices and volumes of commodity exports. Nominal interest rates finally rose to meet and exceed inflation, bringing a sharp switch from negative to positive real rates. Higher nominal rates also reduced debtor liquidity by shifting the burden of debt repayment towards the present (the tilt effect). Then as inflation subsided, nominal interest rates fell less quickly, and real rates rose further (see Figure 3). Voluntary lending to LDCs by the commercial banks evaporated after the Mexican crisis of August 1982; the Polish debacle of early 1981 had already hit lending to Fastern Furope and put Hungary and Romania in deep trouble.48 A wave of debt reschedulings followed: there were a total of 36 "multilateral debt renegotiations" in 197581 covering $\$ 19.6$ billion of debt; then 10 in 1982 (\$2.4 billion), 32 in 1983 alone ( $\$ 51.7$ billion), with some slackening in 1984, but a record number of 41 reschedulings signed in 1985 dealing with $\$ 92.8$ billion of debt.49 Lenders reacted to new information about global economic conditions and individual debtors with a generalized, discrete change of regime in credit markets. Rather than a continuous tightening of terms and constraints for borrowers, this was a shift to credit rationing.

This change of credit-market regime was a response to macroeconomic shocks exogenous to the credit markets whose effects conveyed new information to lenders. 50 Imperfect information about one or at most a few borrowers was generalized to others, and lenders' overall perceptions changed. The "disaster myopia" emphasized by Guttentag and Herring (1984, 1985) was dispelled by 


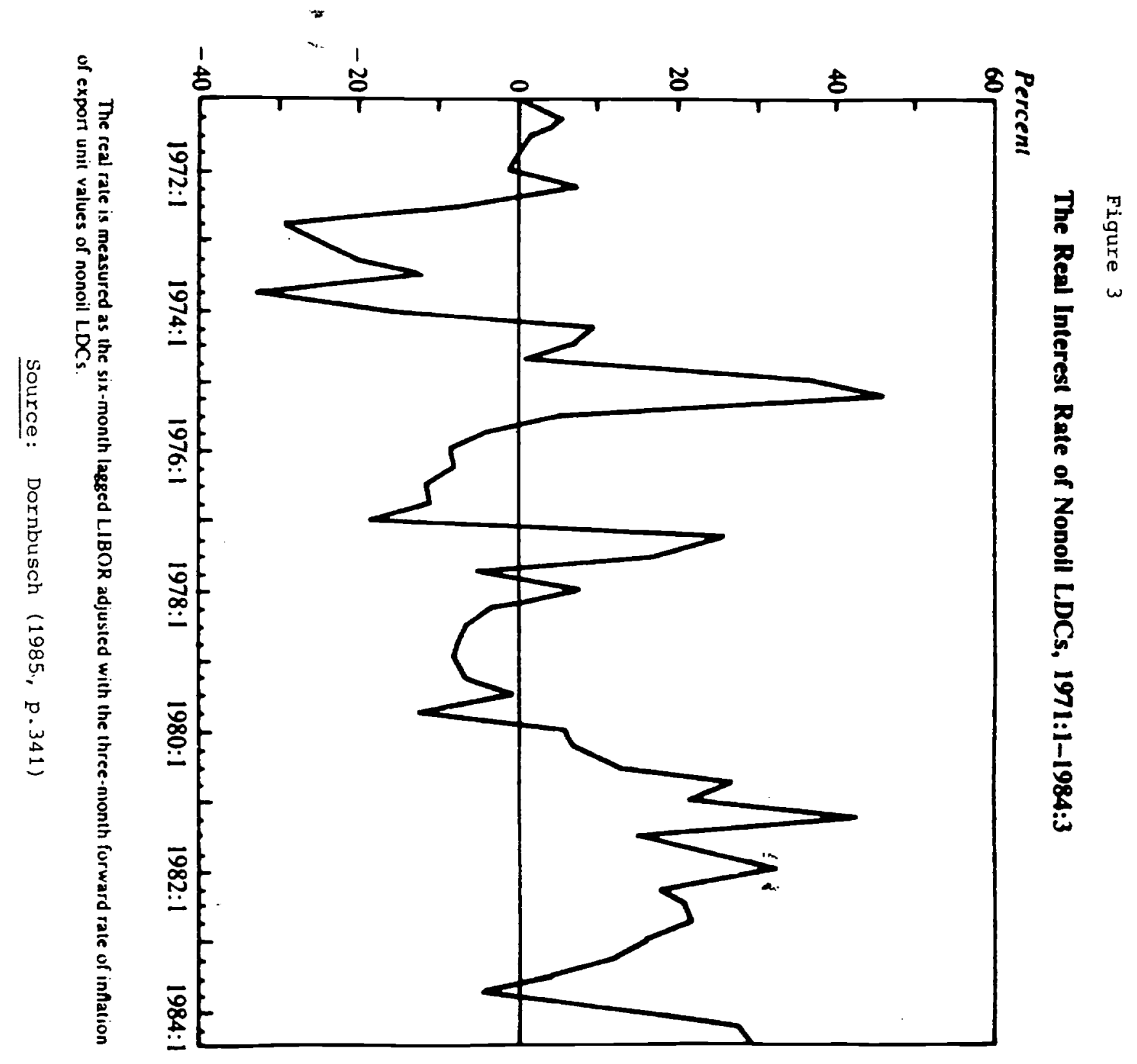


such information; and when the disaster scenario suddenly took on a non-negligible subjective probability, lenders whose sole protection was to try to maintain short loan maturities could react only by pulling out of the market wherever possible.

The magnitude of the shocks which so dramatically affected lenders' behaviour can be seen in Tables $11-13$ and Figures 3 and 4. The rise of 20 percentage points in real interest rates on floatingrate debt from 1980 to 1981 is extraordinary. The fall in real commodity price (excluding oil) of 26 per cent from 1980 Q1 to 1983 Q1 is of a similar magnitude to fifty years previously. Although the terms of trade of non-oil LDCs (NLDCs) had peaked in 1977 Q1, the decline of 18 per cent from 1979 Q1 to 1983 Q1 was still substantial. The total effect in terms of real income is shown in Table 13; for the non-oil debtors (excluding Argentina), there were losses in GDP from three to six per cent. As a real income loss, this might be tolerable; as a required increase in transfer abroad, it was indeed onerous. 51

Consequences for the debt burden are shown in Tables 14 and 15 . Beginning in 1980, total indebtedness rose rapidly for the NLDCs, and by 1982 their debt-export ratios far exceeded the levels recorded in Table 2 for 1929 (which refer, however, only to central government debt, whereas the recent data cover all foreign liabilities). Most may still have been "solvent" on a suitable long-run calculation, 52 but with uncertain expectations, the distinction between insolvency and illiquidity for a sovereign debtor is both theoretically imprecise and politically untenable. Certainly liquidity was impaired by the withdrawals of short-term 


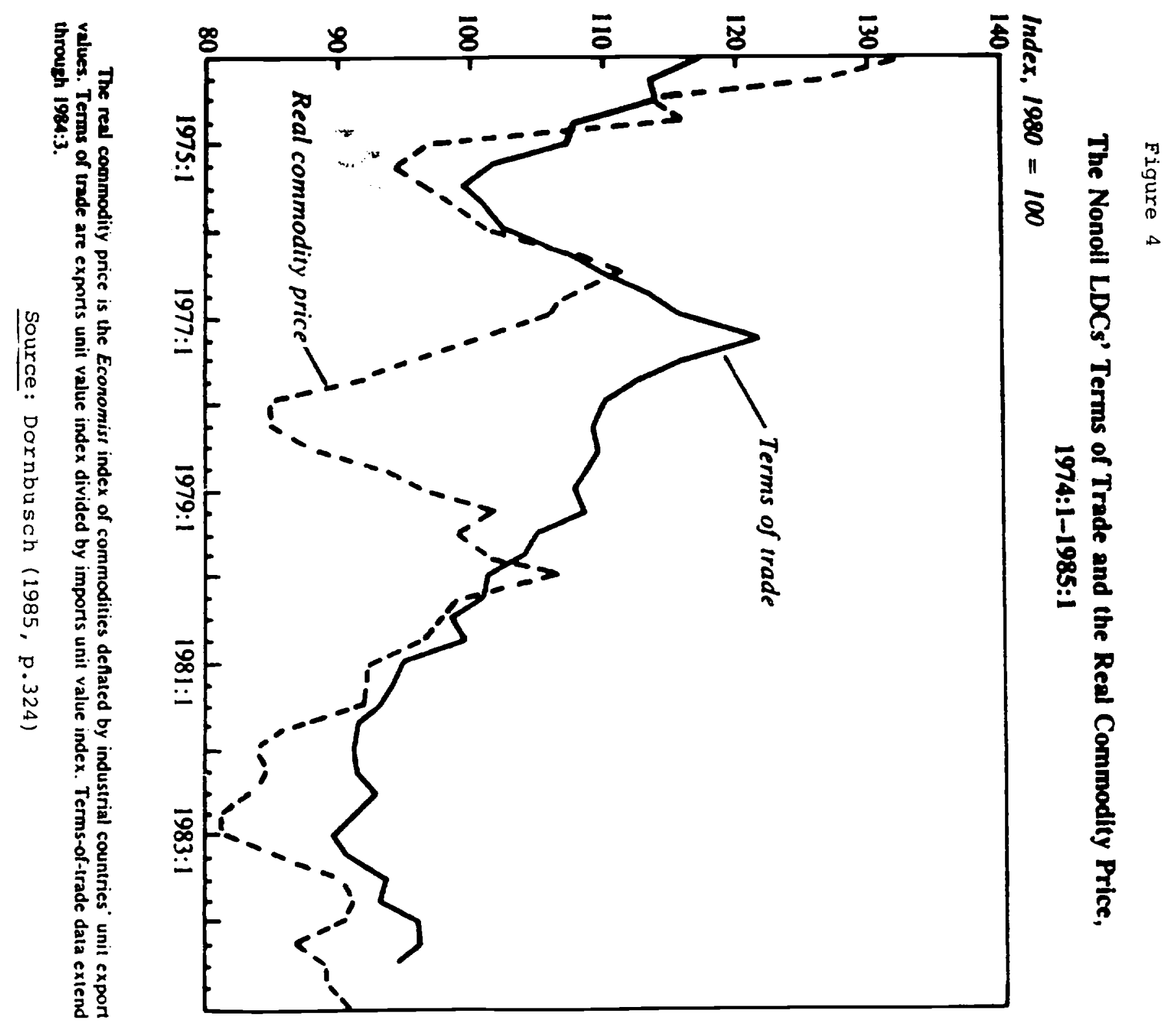


TABLE 11

Average Real Percentage Interest Rate on IDC Floating-Rate Debt

\begin{tabular}{lllllll}
\hline 1977 & 1978 & 1979 & 1980 & 1981 & 1982 & 1983 \\
\hline-11.8 & -7.4 & -9.7 & -6.0 & 14.6 & 16.7 & 15.9 \\
\hline
\end{tabular}

Source: Maddison (1985, p.47). 
TABLE 12

Commodity price indices

$(1980=100)$

\begin{tabular}{|c|c|c|c|c|c|c|c|}
\hline & 1979 & 1980 & 1981 & 1982 & 1983 & 1984 & $\underline{1985}$ \\
\hline Coffee (N.Y.) & 112.5 & 100.0 & 76.8 & 83.4 & 84.9 & 93.7 & 88.6 \\
\hline Copper (London) & 90.3 & 100.0 & 79.8 & 67.8 & 72.9 & 63.0 & 64.9 \\
\hline $\begin{array}{l}\text { Petroleum } \\
\text { (Venezuela) }\end{array}$ & 60.8 & 100.0 & 116.1 & 116.1 & 101.6 & 97.9 & $97.9^{*}$ \\
\hline $\begin{array}{l}\text { Rubber } \\
\text { (Singapore) }\end{array}$ & 88.6 & 100.0 & 78.8 & 60.2 & 74.7 & 67.2 & $53 \cdot 3$ \\
\hline $\begin{array}{l}\text { Sugar (EEC } \\
\text { Import price) }\end{array}$ & 87.4 & 100.0 & 83.7 & 82.0 & 79.5 & 72.6 & 72.4 \\
\hline Tin (London) & 92.1 & 100.0 & 84.5 & 76.5 & 77.4 & 72.9 & 68.7 \\
\hline
\end{tabular}

Quarter II

Source: International Financial Statistics 1985 Yearbook. 


\section{External Shock, 1979-83}

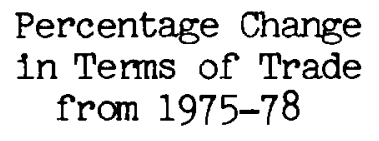

Real Income Effect as Percentage of GDP

\begin{tabular}{lrrr} 
& & & \\
\cline { 3 - 3 } & 3 & 0.2 & 1.6 \\
Argentina & -29 & -2.3 & -5.0 \\
Chile & -27 & -4.9 & -6.2 \\
Mexico & 26 & 1.8 & 1.2 \\
Peru & -22 & -3.7 & -4.2 \\
Venezuela & 64 & 15.9 & 16.2 \\
Colombia & -18 & -2.0 & -2.8 \\
Indonesia & 36 & 6.1 & 6.2 \\
Korea & -3 & -0.9 & -3.8 \\
Malaysia & 14 & 4.9 & 4.8 \\
Thailand & -14 & -2.9 & -3.3 \\
Philippines & -16 & -3.2 & -3.9
\end{tabular}

Sum of Real Interest Rate and Terms of Trade Effects on GDP (Percentage)

Source: Sachs (1985, pp.527-8). 
Gross Extermal Liabilities and Short-Term Component

(b1llion US dollars, end-year)

\begin{tabular}{|c|c|c|c|c|c|c|}
\hline & & 1978 & 1980 & 1981 & 1982 & 1983 \\
\hline Argentina & $\begin{array}{l}\text { Total } \\
\text { S }\end{array}$ & $\frac{13.3}{3.4}$ & $\frac{27 \cdot 3}{10 \cdot 5}$ & $\frac{33.7}{11.0}$ & $\frac{43.6}{16.5}$ & $\frac{46.0}{9.4}$ \\
\hline Braz11 & $\begin{array}{l}\text { Total } \\
\mathrm{S}\end{array}$ & $\frac{53.4}{7.1}$ & $\frac{70.0}{13.5}$ & $\frac{79.9}{15.3}$ & $\frac{91.0}{17.4}$ & $\frac{95.5}{14.2}$ \\
\hline Mexico & $\begin{array}{l}\text { Total } \\
\mathrm{S}\end{array}$ & $\frac{35.7}{4.9}$ & $\frac{57.1}{16.2}$ & $\frac{77.9}{25.0}$ & $\frac{85.8}{26.1}$ & $\frac{93.7}{10.1}$ \\
\hline Peru & $\begin{array}{l}\text { Total } \\
\text { S }\end{array}$ & $\frac{9.7}{2.1}$ & $\frac{10.0}{2.1}$ & $\frac{10.3}{2.5}$ & $\frac{12.2}{3.1}$ & $\frac{12.4}{1.4}$ \\
\hline Venezuela & $\begin{array}{l}\text { Total } \\
\mathrm{S}\end{array}$ & $\frac{16.8}{8.0}$ & $\frac{29.6}{15.5}$ & $\frac{31.9}{17.0}$ & $\frac{31.8}{14.7}$ & $\frac{32.2}{14.5}$ \\
\hline Nigeria & $\begin{array}{l}\text { Total } \\
\text { S }\end{array}$ & $\frac{5.5}{2.4}$ & $\frac{9.0}{3.5}$ & $\frac{11.9}{4.4}$ & $\frac{14.2}{4.3}$ & $\frac{19.7}{6.7}$ \\
\hline Korea & $\begin{array}{l}\text { Total } \\
\mathrm{S}\end{array}$ & $\frac{17 \cdot 3}{4.5}$ & $\frac{29.3}{10 \cdot 1}$ & $\frac{34.2}{11.6}$ & $\frac{38.3}{13.6}$ & $\frac{40.4}{12.1}$ \\
\hline Indonesia & $\begin{array}{l}\text { Total } \\
\text { S }\end{array}$ & $\frac{18.0}{1.8}$ & $\frac{29.9}{2.8}$ & $\frac{22.7}{3.3}$ & $\frac{26.5}{4.8}$ & $\frac{30.2}{4.6}$ \\
\hline Ph1lippines & $\begin{array}{l}\text { Total } \\
\mathrm{S}\end{array}$ & $\frac{10.8}{3.9}$ & $\frac{17.4}{7.6}$ & $\frac{20.8}{9.4}$ & $\frac{24.2}{11.3}$ & $\frac{23.9}{9.4}$ \\
\hline Yugoslavia & $\begin{array}{l}\text { Total } \\
\text { S }\end{array}$ & $\frac{12.5}{1.2}$ & $\frac{18.5}{2.1}$ & $\frac{20.7}{2.5}$ & $\frac{20.0}{1.8}$ & \\
\hline
\end{tabular}

Note: Short-term liabilities $S$ are those of original maturity less than one year.

Source: World Bank, World Debt Tables, 1985-86 edition. 
Ratio of Gross External Liabilities to Exports of Goods and Services (percentage)

$\begin{array}{lrrrrrr} & 1978 & \underline{1980} & \underline{1981} & \underline{1982} & \underline{1983} & \underline{1984} \\ \text { Argentina } & 169 & 244 & 285 & 449 & 471 & 464 \\ \text { Braz1l } & 369 & 301 & 296 & 388 & 392 & 345 \\ \text { Mexico } & 313 & 232 & 256 & 310 & 327 & 301 \\ \text { Peru } & 401 & 206 & 243 & 292 & 323 & 331 \\ \text { Venezuela } & 154 & 133 & 130 & 158 & 186 & 182 \\ \text { Nigeria } & 45 & 33 & 61 & 110 & 179 & 160 \\ \text { Korea } & 101 & 130 & 125 & 135 & 133 & 128 \\ \text { Indonesia } & 159 & 94 & 91 & 125 & 151 & 147 \\ \text { Philippines } & 220 & 214 & 242 & 302 & 294 & 304 \\ \text { Yugoslavia } & 147 & 134 & 131 & 131 & 154 & 144\end{array}$

Source: World Bank, World Debt Tables, 1985-86. 
TABLE 16

\section{Exposure of US Banks to LDC Debtors}

Percentage of Capital

Billion \$US

June 1982

March 1986

March 1986

9 Money Center Banks
All US

Banks

9 Money
Center Banks

All US

Banks
All US banks

$\begin{array}{lrrrrr}\text { Mexico } & 50 & 38 & 38 & 22 & 24.2 \\ \text { Brazil } & 46 & 31 & 37 & 22 & 23.7 \\ \text { Korea } & 19 & 14 & 11 & 9 & 9.4 \\ \text { Venezuela } & 26 & 16 & 16 & 9 & 9.7 \\ \text { Argentina } & 21 & 13 & 14 & 8 & 8.5 \\ \text { Chile } & 12 & 9 & 8 & 6 & 6.3 \\ \text { Philippines } & 14 & 8 & 4 & 5 & 5.0 \\ \text { Colombia } & 8 & 5 & 141 & 88 & 2.3 \\ \text { Non-OPEC LiCs } & 227 & 154 & 33 & 18 & 96.4 \\ \text { OPEC } & 35 & 60 & & 9 & 19.4\end{array}$

Note: Banks' capital defined as equity, subordinated debt and loan-loss reserves. "All US Banks" are those completing Country Exposure Report. Their total capital base rose from $\$ 66.2$ bn. in June 1982 to $\$ 109.7$ bn. in March 1986 .

Source: Federal Reserve Board. 
TABLE 17

Exposure of US and UK banks in Mexico, Brazil, Argentina and Venezuela as Percentage of Capital

\begin{tabular}{lcc} 
& End 1982 & End 1984 \\
\cline { 2 - 3 } Bank of America & 128 & 122 \\
Chase Manhattan & 139 & 142 \\
Manufacturers Hanover & 234 & 173 \\
Chemical & 155 & 134 \\
Bankers Trust & 131 & 114 \\
First Chicago & 123 & 103 \\
Citicorp & n.a. & 140 \\
National Westminster & & 73 \\
Barclays & n.a. & 62 \\
Lloyds & n.a. & 165 \\
Midland & n.a. & 205
\end{tabular}

Sources: Cline (1983, p.34) for 1982 and Lever-Huhne (1985) for 1984. 
TABLE 18

Bank Share Price/Farnings Rat1o as Percentage of Overall Market P/E for UK and US

$\begin{array}{llc} & \text { NYSE } & \text { London } \\ 1970 & \text { n.a. } & 66.9 \\ 1975 & \text { n.a. } & 118.4 \\ 1980 & 62.0 & 52.5 \\ 1981 & 69.8 & 49.7 \\ 1982 & 48.8 & 39.7 \\ 1983 & 49.5 & 51.4 \\ 1984 & 45.5 & 47.5 \\ 1985 \text { (Jan-July) } & 49.6 & 56.7 \\ 1986 \text { (J) } & 56.8 & 46.1\end{array}$

At 15 August each year except 1986.

Source: Financial Times, Datastream. 
funds in 1982-3 evident in Table 14; together with capital flight, they significantly increased the disaster probability. That reaction could have activated linkages I, V and VI which proved so devastating in the 1930s. The "debt strategy" was designed entirely to contain it.

The dangers are evident from the data on bank exposure in Tables 16 and 17 and on bank share prices in Table 18. The tJS banks did not begin to recover from the 1982 plunge in their relative price/earnings ratios until 1986, partly because of their subsequent problems with energy and real estate loans. The UK banks have fared somewhat better but show no sign of regaining the standing they enjoyed in the 1970s.

Many useful case studies treat the impact of the debt crisis on individual countries and regions and their responses. 53

Nevertheless, we require much more empirical evidence on the role of information about debt-servicing difficulties and their causes. How do the markets perceive such information, process it, and then react to individual borrowers and classes of borrowers? For example, we have two contradictory assessments of market evaluations of Mexican securities in the period leading up to August 1982, one finding a continuous deterioration from the previous winter, the other observing a discontinuous plunge shortly before the crisis became manifest. 54 How the market performs before a crisis is important in assessing whether shifting more sovereign debt into the market through securitization is likely to make the system more or less stable.

The response of policy-makers to the debt crisis assumed that 
it was essentially and almost everywhere a problem of liquidity rather than solvency, ignoring questions about the legitimacy of that distinction. This approach may have been adequate in the short run, when the key to avoiding financial crisis was maintaining confidence. On plausible assumptions about growth, interest rates, adjustment policies, industrial-country macro policies, and the provision of bridging loans, projections showed substantial improvement in the debt indicators during 1984-86 and a progressive dissipation of the crisis thereafter. 55

The IS government's optimism did not last; hence the Baker Plan in autumn 1985. For the objective of avoiding a financial crisis, however, the strategy has been almost completely successful so far in keeping both creditors and debtors on board. Neither the reasons nor the prospects for continued success are entirely obvious. There exist clear, level-headed, well-informed evaluations of the costs and benefits of default to debtors which imply that there are cases in which the benefits exceed the costs. 56 As long as rescheduling continues to eschew debt relief, this will remain the case; yet historical comparisons suggest the likelihood of some element of write-off, some ultimate sharing of the burden between creditors and debtor. 57 The question is whether there are circumstances in which debt relief or write-offs are possible without financial crisis.

The answer requires a judgment of the overall health of the international banking system and a scenario for how the authorities would react. Recently the banks have been building up their capital base while writing off some sovereign debt (see Table 16). There 
remain problems on the asset side. Keeping maturities short has little systemic advantage, since that just increases the competition, when trouble threatens, to exit first and leave the problem to other banks. It can be argued that some of the banks' off-balance-sheet activities that have grown so fast recently are relatively risky. On the other hand, securitization on the liability side of banks' balance sheets reduces their dependence on the highly volatile international interbank market.

\section{Iinkages}

The discussion of recent disturbances and their management now permits a comparison between the two periods of the operation of the linkages we have stressed.

(I) Whereas the events threatening debt default endangered the banks of some debtor countries in the 1930s, the creditor-country banks did not then hold enough sovereign debt to make it a problem for them. In the current period, there have been a few instances of the former linkage (Argentina had domestic financial difficulties at a critical juncture in its debt-servicing problems). The major effort today, with banks having assumed the credit risks formerly borne by purchasers of sovereign bonds, is to contain any menace this poses for the financial system. So far, direct policy intervention by national authorities and international institutions has succeeded almost entirely in protecting the banking system from major harm.

(II) There have been no bank failures so spectacular as themselves to provoke debt default. 
(III) In the 1930s, withdrawals of short-term funds sometimes brought the authorities to restrict convertibility in order to avoid debt default. Recently, exchange-rate overvaluation without exchange controls has brought capital flight, which has played a greater role in the buildup to debt crisis than in the earlier period (although capital movements were important in the propagation of crises in both periods). Failure to block this linkage has been a key weakness in present-day arrangements relative to those of the 1930s. There is a further, indirect linkage from exchange-market disturbances to debt-servicing difficulties which is a major threat today: exchange-rate misalignments have caused pressures for protectionist trade policies, which impede the ability of debtor countries to earn the export surpluses they require.

(IV) Whereas debt default did not generally force down the debtor's exchange rate in the 1930s, the burden of debt service has clearly had that effect even for non-defaulting debtors today. Pressures from the government budget and the need to run current account surpluses both work in this direction, insofar as depreciation relieves the financial burden of supporting an overvalued rate while raising net exports.

(V) Instability in the foreign exchange markets was a major cause of generalized financial instability in the 1930s. In the recent period, it has endangered banks only insofar as some of them have sought too aggressively to profit from speculation in these markets.

(VI) In the earlier period, bank failures caused pressures on the home country's currency by provoking capital flight, and 
occasionally on the currency of a major foreign creditor (recall how the pound weakened due to the problems of Austrian and German banks). Recently, tremors in the US banking system appear to have made the foreign exchange markets nervous, but this has not been a significant consideration.

\section{Institutional Change and Public Policy}

Partly in reaction to the problems faced by the banks, international credit flows have in the past few years shifted from bank lending towards direct credit markets. Simultaneously, there has been an explosion of new financial markets and financial instruments, primarily because technological innovation has substantially reduced transactions costs. 58

In principle, reduction in interbank linkages should reduce systemic vulnerability. The "Cross Report" (Bank for International Settlements, 1986), however, points out some countervailing aspects of recent trends: the quality of banks' loan assets may decline; the narrower base of the system may make it less reponsive to sudden liquidity needs; non-bank capital markets may have less information on borrowers, less opportunity to screen and to monitor performance, and less capacity to arrange refinancing packages for those in debtservicing difficulties; and many of the new services banks are providing appear to be underpriced, so that they are not providing earnings commensurate with their risks.

These trade-offs are complicated, and the pace of change has been so rapid that there is little contemporary experience from which to generalize. On the basis of interwar experience, these 
developments appear to be mainly positive from the viewpoint of financial stability. Our study of linkages suggests that incomplete and imperfect information favors the generalization of adverse shocks into full-fledged crises; that macroeconomic instability is the prime source of those shocks; and that appropriate action by the regulatory and monetary authorities can block the most dangerous linkages. Such action in the "debt strategy" has avoided defaults and widespread bank failures to date. But it was the system of bank lending to sovereign borrowers that permitted the accumulation of excessive debt burdens, and the rescheduling process which has so far prevented defaults is maintaining almost the full weight of those burdens on the debtors.

In the 1930s, as during the century of international lending before World War I, creditors too assumed a share of the losses created by adverse shocks. The problem then was that when the shocks were global, the contagious, infectious nature of default contributed to financial crisis, disrupting the allocative mechanisms of the international capital market. We now have much more sophisticated public health measures, both macroeconomic and regulatory. They can cope with the dangers of securitization while the financial system switches from relationship- towards transaction-basea banking.

Securitization will get more information into the market place. This should reduce adverse selection; substitute more frequent, smaller, visible shocks for the major upheavals which arise when relationships go wrong; and remove from the banking system the heavy burden of having to act as a buffer when shocks do occur. It is not 
evident that underpricing of new financial services exceeds the inadequacy of spreads in allowing for the default risk on bank lending to sovereign borrowers in the 1970s ("disaster myopia"); while the ex-post rates of return on international lending of the 1920 s appear to have been relatively favorable for the lenders. 59 Calls for more formal international-lender-of-last-resort (ILLR) arrangements ${ }^{60}$ should not obscure the substantial development of both domestic and international LLR facilities over the past fifty years, as well as a much more sophisticated regulatory system. In the 1930s, financial weakness affected mainly the large banks in Europe, while in the United States it characterized the entire spectrum of the banking system. Now small banks are protected on the liability side by deposit insurance which limits runs, 61 and large ones in difficulty are handled directly by domestic LLRs. Internationally, the "Paris Club" arrangements have for over two decades effectively handled rescheduling of official or governmentguaranteed lending to sovereign debtors. The International Monetary Fund acts in a signalling capacity, providing the capital market with information on debtors and so reducing the risk that the difficulties of one will be transmitted infectiously to others who are creditworthy. IMF conditionality helps to maintain the standing of the debtor and its obligations, thereby limiting the risk of contagious transmission of financial illness to its creditors. And in contrast with the 1930s, the IMF can act to promote a rescheduling before default, whereas then default was needed to provoke direct negotiations between a sovereign debtor and representatives of its creditors. 62 This ex ante bargaining should 
in principle benefit both creditors and debtors; in practice, who gains how much from rescheduling is highly controversial.

Coordination of prudential supervision has taken place primarily under the auspices of the Bank for International Settlements. The Basle concordat of 1975 , as revised in 1983 , explicitly disclaims any ILLR responsibilities. The authorities' key principle is to exercise supervision on a consolidated basis. They do have a clear understanding of how responsibilities are shared between home and host central banks, and the individual regulatory authorities are much more experienced than they were fifty years ago. It has been difficult for them, however, to keep abreast of internationalization and financial innovation.

The key problem facing any LLR is moral hazara.62a the classic answer is that the LIR is responsible for the money supply avoiding financial crisis by containing any threat to the credit base - rather than for the survival of any particular financial institution. The internationalization of the interbank market has made this distinction harder to maintain, however, and no authority or institution currently has responsibility for the world money supply. There is no true ILLR, although the functions which one might fulfil are much better understood now than they would have been in the 1930s (as can equally be said of domestic LTRs).

Nevertheless, success in blocking the transmission of destabilizing shocks in the 1980 s owes much to the ILLR-style activities of certain participants. The US Federal Reserve Board and Treasury sometimes seem to forget that the United states is supposed to have lost its hegemonic role. Whether by itself, as 
when domestic monetary policy was eased in autumn 1982 in response to signs of financial distress, $62 \mathrm{~b}$ or in collaboration with the IMF, notably in dealing with Mexicoin both 1982 and 1986, or coordinating its major Western partners, as at the Plaza Hotel in 1985, the United States has shown itself capable of leadership. Neither the commitment to "hands-off" economic policies nor the decline of internationalism in the United States has inhibited decisive action when American vital interests are at stake.

Sometimes others play this role, as did the fovernor of the Bank of England in arranging a bridging loan for Hungary through the BIS in spring 1982. Yet unless and until more formal institutional arrangements are established, the United States will continue to be the key player - if it wishes - in forcing action on debt strategy, exchange rates and macroeconomic policy coordination, and hence in preventing financial crisis.

\section{The Future}

There are still plausible disaster scenarios. Marris (1985) on macro policy imbalances and their consequences (the "hard landing") and Lever and Huhne (1985) on debt both permit the imagination to run to deep financial crisis. We believe, however, that greater understanding today of the linkages in financial crisis may have helped to reduce the danger of a serious crisis. Market participants and policy-makers may have learned from the experience of several smaller disturbances since the early 1970 s that disaster probabilities are not negligible and appropriate precautions should be taken. 
The main dangers lie not in disturbances originating in financial markets but in malfunctions of the real economy. Even though we have not experienced a crisis that seriously disrupted its allocative role, the international capital market still does not appear to be working properly, with the bulk of net flows now going from areas of high real marginal productivity to areas of lower productivity. Sustained high unemployment still fosters protectionism and threatens trade policy conflicts, with the "inward-looking" consequences characteristic of the 1930s.63 Although there has been more international macroeconomic policy cooperation recently, it is not fully institutionalized and may prove transient 64 - there is no international monetary constitution providing rules on exchange-market intervention and choice of reserve asset, constraints on fiscal and monetary policies, or responsibility for the ILLR function. Policy-makers still try to maintain their autonomy in an increasingly interdependent world. Paradoxically, even that objective, in the sense of expanding their opportunity set, might best be achieved through international economic policy coordination. Markets could not do the job, even if individual domestic policies were independently "optimal".

IV. Conclusion

In this paper, we have contrasted the international financial crisis of the 1930 s with the recent performance of the global financial system. We have sought to provide a perspective on the prospects for continued stability in international capital markets. While exhibiting fundamental differences in the operation of these 
markets currently and during the 1930s, our analysis nonetheless yields conclusions regarding conditions conducive to both the maintenance of stability and the onset of crisis.

The most important of these conclusions concern the roles of regulatory and stabilization policies. Financial crises spread most quickly when information is least complete, and they result in major externalities for particular sectors and the macroeconomy. On both imperfect information and externality grounds, there is a rationale for government intervention. Financial crises pose a greater threat under some institutional configurations than others. Even when the benefits of financial deregulation are apparent, there is a role for regulatory policy in channeling financial innovation in directions that leave the world economy less vulnerable to financial collapse. Finally, we have seen that financial crises are as much the result of macroeconomic shocks as they are of perturbations originating in financial markets. Perhaps the most important policy to prevent financial crises is therefore to provide a stable - and, in an increasingly interdependent world, internationally coordinated macroeconomic environment within which financial markets may function.

The main difference between now and fifty years ago is that we have been there before and do not want to return. Informed policies can help us to avoid epidemic and keep our anatomy lesson to the conference room rather than the mortuary. 


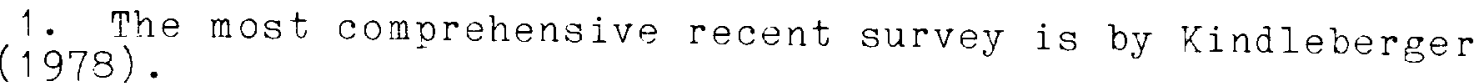

2. This same point is made by Goldsmith (1982), p.42.

3. Other exchanges, including those of Italy, the Netherlands, Spain, Sweden, Japan, Argentina and Brazil, remained stable even at
war's end.

4. See the introduction to Eichengreen (1985a) for details.

5. Documenting the franc's undervaluation is problematic, however; see Eichengreen and Wyplosz (1986). Conventional accounts typically suggest that the franc was some 10 to 15 per cent undervalued relative to the dollar.

6. The transition from the gold to the gold-exchange standard is analyzed in Eichengreen $(1985 \mathrm{~b})$. We return below to the role of
foreign deposits.

6a. Two views of the policy coordination problem are clarke (1967) and Eichengreen (1985b).

7. The information summarized here is taken from Eichengreen and Portes (1986).

8. The parallels between the two experiences are explored by Balogh and Graham (1979).

9. Many articles in the financial press could be cited. An example is the Financial Times (18 December 1929), which even at this late date calls Peru "apparently a country with a bright
future."

10. See for example Winkler (1933) or Securities and Fxchange Commission (1937). Mintz (1950, ch.4) presents evidence that a few aggressive issue houses were responsible for a disproportionate share of the loans which ultimately went into default.

10a. The Table? data on ratios of public debt to gNP must be interpreted with care, since the importance of state and municipal borrowing varied enormously across countries. The low ratio for Germany, for example, reflects the tendency for borrowing to originate with municipalities and not the Reich.

11. Latin American experience is described in Eichengreen (1986)

and Central European reforms in Nurkse (1946).

12. League of Nations (1931), p.14.

13. Details are to be found in Schedvin (1970).

14. Schedvin (1970), pp.166-167. 
15. Insofar as exchange-rate fluctuations due to devaluation disrupted trade, a linkage to which contemporaries attached much importance, export receipts and debt capacity were reduced still further. For example, Condliffe (1933, p.221) writes that "exchange instability resulting from the breakdown of the international gold standard was one of the principal causes of further economic deterioration in 1932 and figured prominently among the factors which limited and checked the revival of prices and productive capacity in the third quarter of that year." For similar comments, see Nurkse (1944). We return below to evidence on the impact of exchange-rate volatility on trade.

16. This periodization follows Condliffe (1933), chapter IX.

17. The situation in 1931 differs from Sachs's (1982) description of pre-World-War-I lending and default. Before World War I, Sachs argues, default by one country did little to interrupt the flow of capital to other borrowers. The difference between the periods may be that default in 1931 was seen as a response to global rather than country-specific shocks.

18. Eichengreen and Portes (1986) report regressions in which both the extent of terms-of-trade deterioration and the growth of the central government budget deficit are significantly correlated with the incidence and extent of default.

19. British Public Record Office (PRO) FO371/14198, Dispatch to Foreign Office by R.C. Mitchell, "Political Situation in Bolivia," 22 September 1930.

20. PRO F0371/14253, Dispatch from Mr. Gurney (Lima), "Annual Report of the Peruvian President to Congress," 18 September 1930; Madden et al. (1937), p.111.

21. Bank Commissioner of the State of Vermont (1930). Vermont appears to be the only state for which this information is available. See White (1984) for further discussion of these data.

22. See Leguizamon (1933) for additional analysis.

23. Kindleberger (1984), p.372. It is popularly thought that origins of the run were both economic, caused by the bank's uncertain liquidity, and political, caused by French alarm over the recently proposed Austro-German customs union.

24. A recent account of this episode is James (1984).

25. It could be argued that the provision of deposit insurance and improvements in bank regulation have reduced the extent of these externalities. We return to this point below.

26. See League of Nations (1934) for another statement of this view.

27. Details are to be found in Cairncross and Eichengreen (1983) 
and the references cited there.

28. Between June 1922 and June 1929, the real estate loans of commercial banks had risen by 128 per cent and their security loans by 77 per cent, in comparison with all. other loans and investments, which rose by only 30 per cent.

29. The ratio of cash reserves to total deposits was consistently lower only in countries which ultimately turned to exchange control (Germany, Austria, Czechoslovakia) and in the exceptional Swedish
case.

30. This is similar to the argument advanced by Bernanke (1983).

31. This episode is the subject of Epstein and Ferguson (1984).

32. Beenstock (1984) argues that this difference has no significant systemic consequences; and the 1970 s may turn out to have been a quite exceptional period in this regard, with the growth of securitization and off-balance-sheet operations in the past few
years.

33. There were negotiations between debtor countries and the bondholders' organizations after the defaults of the $1930 \mathrm{~s}$, but they were difficult to organize. See Eichengreen and Portes (1986).

34. See Williamson (1977) for an account of this period.

35. See Padoa-Schioppa's essay (1985) for background on the operation of the FMS and the detailed discussions and assessments in the report (and background documents) of the mreasury and Civil Service Committee of the UK House of Commons (1985).

36. The studies which supposedly showed the inefficacy of sterilized intervention were ignored when the United States changed its policy stance in september 1985.

37. Recent accounts, from somewhat different viewpoints, include 38. OECD (1983) describes the picture at the beginning of the $1980 \mathrm{~s}$, and Bryant (1986) offers a more recent and more analytical assessment.

39. See Kindleberger (1978, 1986).

40. Generally, capital controls have been progressively liberalized or removed, notably in the UK. It can be argued that they have played an important role in keeping the EMS together - or that the demands of keeping the system together have required capital controls (Giavazzi and Giovannini, 1986). This view is likely to be tested soon, as France and Italy proceed to relax exchange controls.

41. See Kenen and Rodrik (1986). 
42. See Rogoff (1985), Padoa-Schioppa (1985), House of Commons $(1985)$.

43. See de Grauwe and de Bellefroid (1986) and Kenen and Rodrik $(1986)$

44. See Prankel and Froot (1986) and references cited there.

45. The estimates in World Financial Markets (March 1986) are particularly striking, though controversial (according to the Financial Times 21 August 1986, the Bank of Mexico estimates capital flight under the current government at $\$ 2$ billion, in contrast to the Morgan Guaranty estimate of $\$ 17$ billion). A more academic but still debatable analysis stressing the role of capital flight in Latin American debt problems, and the root cause of exchange rate overvaluation, is given by Sachs (1985).

46. The view of Marris (1985) are discussed below.

47. Diaz-Alejandro (1984) argues that an observer in 1980-81 could not reasonably have foreseen a crisis of the magnitude experienced in 1982-84. On the other hand, Portes (1977) predicted a debtservicing crisis for several East European countries in the early 1980 s, beginning with a rescheduling for Poland in 1980-81.

48. See Portes (1982).

49. World Bank (1986).

50. As suggested by theory; see, for example, Guttentag and Herring (1984). Their argument that an extended period without adverse shocks creates conditions in which a shock will then provoke discontinuous market behaviour is more specific and rigorous than the "financial instability hypothesis" of Minsky (1982), who argues that the danger of financial crisis builds up over an extended period of prosperous times.

51. Cf. footnote 18 above.

52. See Cohen (1985).

53. Notable among these are Kraft (1984), who gives an "inside", circumstantial narrative of the negotiations which dealt with the initial Mexican crisis, and Fraga (1986), who makes an interesting comparison of Brazil's recent experience with Germany and reparations fifty years before.

54. Compare Guttentag and Herring (1985) with Fdwards (1986).

55. "With reasonable recovery in the global economy, the problem of international debt should prove manageable and the degree of its current risk to the international system should decline (cline, 1983, p. 121)."

56. See Kaletsky (1985) and Lever and Huhne (1985). 
57. See Eichengreen and Portes (1986) for calculations of the ex-post rates of return earnel by creaitors in such cases.

58. Cooper (1986) describes these changes and argues convincingly

that they are explained better by technical change than as

innovative risk-sharing arrangements or as responses to crossborder differences in taxation and regulation.

59. Eichengreen and Portes (1986).

60. For example, see Guttentag and Herring (1983).

61. The models of the U.S. Federal Deposit Insurance Corporation and Federal Savings and Ijoan Insurance Corporation have been increasingly followed in Furope and elsewhere.

62. Eichengreen and Portes (1986).

62a. Solow (1982) provides a recent discussion of the theory relevant to LLR functions, which are treated further in Kindleberger (1978) and Kindleberger and Laffargue (1982). It can be argued that financial deregulation has led to more risk-taking by financial intermediaries, hence to more LIR intervention, exacerbating moral hazard (and weakening monetary control). This goes beyond our scope here.

62b. See Carron (1982).

63. See Cooper (1983).

64. See Portes (1986). 
Balogh, Thomas and Andrew Graham (1979), "The Transfer Problem Revisited: Analogies Between the Reparations Payments of the 1920s and the Problem of the OPEC Surpluses," Oxford Bulletin of Economics and Statistics 41 , pp.183-192.

Bank for International Settlements, 1986, Recent Innovations in International Banking, Basle.

Beenstock, M. (1984), The World Economy in Transition, London: Macmillan.

Bernanke, Ben S. (1983), "Nonmonetary Effects of the Financial Crisis in the Propagation of the Freat Depression," American Economic Review 73 , pp. 257-276.

Bryant, Ralph (1986), International Financial Intermediation: Issues for Analysis and Public Policy, manuscript, Washington: Brookings Institution.

Buiter, William and Richard Marston, eds. (1985), International Economic Policy Coordination, Cambridge: Cambridge University Press.

Butlin, N.G. (1984), "Select Comparative Economic Statistics, 19001940," Source Paper No. 4, Department of Economic History, Australian National University.

Cairncross, Alec and Barry Eichengreen (1983), Sterling in Decline, Oxford: Blackwell.

Carron, Andrew (1982), "Financial Crises: Recent Experience in US and International Markets", Brookings Papers on Economic Activity No. 2, pp. 395-422.

Clarke, S.V.O. (1967), Central Bank Coordination, 1924-31, New York: Federal Reserve Bank of New York.

Cline, William (1983), International Debt and the stability of the World Economy, Washington, DC: Institute for International Economics.

Cline, William (1984), International Debt: Systemic Risk and Policy Response, Washington, DC: Institute for International Economics.

Cohen, Daniel (1985), "How to Evaluate the Solvency of an Indebted Nation," Economic Policy 1, pp.139-167.

Commonwealth Secretariat (1984), The Debt Crisis and the World Economy, London.

Condliffe, J.B. (1933), World Economic Survey, 1932-33, Geneva: League of Nations.

Cooper, Ian (1986), "Financial Markets: New Financial Instruments," 
paper presented to CEPR Workshop, London.

Cooper, Richard (1983), "Managing Risks to the International

Economic System," in Herring, Richard, ed., Managing International Risk, Cambridge: Cambridge University Press.

Diaz-Alejandro, Carlos (1984), "Latin American Debt: I Don't Think We Are in Kansas Anymore," Brookings Papers on Economic Activity No. 2, pp.335-389.

Dornbusch, Rudiger (1985), "Policy and Performance Links between LDC Debtors and Industrial Nations," Brookings Papers on Economic Activity No. 2, pp.303-356.

Edwards, Sebastian (1986), "The Pricing of Bonds and Bank Loans in International Markets," European Economic Review 30, pp.565-590.

Eichengreen, Barry (1985a), ed., The Gold Standard in Theory and History, London: Methuen.

Eichengreen, Barry (1985b), "International Policy Coordination in Historical Perspective: A View from the Interwar Years," in Buiter and Marston (1985), pp.139-178.

Eichengreen, Barry (1986), "House Calls of the Money Doctor: The Kemmerer Missions to Latin America, 1923-1931," in Ronald Findlay et al. (eds), Debt, Stabilization and Development: Essays in Honor of Carlos F. Diaz-Alejandro, Oxford University Press, forthcoming.

Eichengreen, Barry and Richard Portes (1986), "Debt and Default in the 1930s: Causes and Consequences," European Economic Review 30,
pp.559-640.

Eichengreen, Barry and Charles Wyplosz (1986), "The Economic Consequences of the Franc Poincare," unpublished manuscript.

Fipstein, Gerald and Thomas Ferguson (1984), "Monetary Policy, Loan Iiquidation, and Industrial Conflict: The Federal Reserve and the Open Market Operations of 1932," Journal of Economic History XLIV, pp.957-986.

Frankel, Teffrey and Kenneth Froot (1986), "The Dollar as an Irrational Speculative Bubble," Marcus Wallenberg Papers on International Finance, Vol. 1, No. 1.

Fraga, Arminio (1986), German Reparations and Brazilian Debt, Princeton Essays in International Finance No. 153, Princeton, NJ: International Financial Section, Princeton University.

Goldsmith, Raymond (1982), "Comment on Minsky," in Kindleberger and Laffargue (1982), pp.41-43.

Giavazzi, Francesco and Alberto Giovannini (1986), "The EMS and the Dollar," Economic Policy 2, pp.455-485. 
de Grauwe, Paul and Bernard de Bellefroid (1986), "Long-Run

Exchange Rate Variability and International Trade," mimeo.

Guttentag, Jack and Richard Herring (1983), The Lender-of-LastResort Function in an International Context, Princeton Fssays in International Finance No. 151, Princeton, NJ: International

Financial Section, Princeton University.

Guttentag, Jack and Richard Herring (1984), "Credit Rationing and Financial Disorder," Journal of Finance 39, pp.1359-82.

Guttentag, Jack and Richard Herring (1985), The Current Crisis in International Iending, Washington, DC: Brookings Institution.

House of Commons, Treasury and Civil Service Select Committee, 1985, The Financial and Economic Consequences of UK Membership of the European Communities: The European Monetary System, Vols I, II, and Memoranda, Tondon: HMSO.

James, Harold (1984), "The Causes of the German Banking Crisis of 1931," Economic History Review XXXVIII, pp.68-87.

Kaletsky, Anatole (1985), The Costs of Default, New York: Twentieth Century Fund.

Kenen, Peter and Dani Rodrik (1986), "Measuring and Analyzing the Effects of Short-Term Volatility in Real Exchange Rates," Review of Economics and Statistics, p..311-315.

Keynes, John Maynard (1925), "Is Sterling Overvalued?" The Nation and Athenaeum, 4 April.

Kindleberger, Charles (1978), Manias, Panics and Crashes, New York: Basic Books.

Kindleberger, Charles (1984), A Financial History of Western Europe, London: Allen \& Jnwin.

Kindleberger, Charles (1986), "Bank Failures: the 1930s and the 1980s," in The Search for Financial Stability: The Past Fifty Years, San Francisco, California: Federal Reserve Bank of San Francisco.

Kindleberger, Charles and Jean-Pierre Laffargue, eds. (1982), Financial Crises: Theory, History and Policy, London: Cambridge University Press.

Kraft, Joseph (1984), The Mexican Rescue, New York: Group of Thirty.

League of Nations (1931), Commercial Banks, 1913-1929, Geneva: League of Nations.

League of Nations (1934), Commercial Banks, 1925-1933, Geneva: League of Nations. 

League of Nations (1937), Balance of Payments 1936, Teneva: League
of Nations. League of Nations (1938), Balance of Payments 1937, Geneva: League
of Nations.

League of Nations (1945), Economic Instability in the Postwar

World, Geneva: League of Nations.

Leguizamon, Guillermo A. (1933), "An Argentine View of the Problem of Exchange Restrictions," International Affairs, pp.504-517.

Tever, Harold and Christopher Huhne (1985), Debt and Danger:

The World Financial Crisis, London: Penguin.

Maddison, Angus (1985), Two Crises: Latin America and Asia 192938 and 1973-83, Paris: OECD. McNeil, William C. (1986), American Money and the Weimar Republic,
New York: Columbia University Press.

Marris, Stephen (1985), Deficits and the Dollar: The World Economy at Risk, Washington, DC: Institute for International Economics.

Minsky, Hyman (1982), "The Financial Instability Hypothesis:

Capitalist Processes and the Behaviour of the Economy", in

Kindleberger and Laffargue (1982), pp. 13-38.

Mintz, Ilse (1950), Deterioration in the Quality of Foreign Bonds Issued in the United States, 1920-1930, New York: National Bureau

Mitchell, B.R. (1976), European Historical Statistics, London:
Macmillan.

Morgan Guaranty Trust Company of New York, World Financial Markets.

Nurkse, Ragnar (1944), International Currency Fxperience, Geneva:
League of Nations.

Nurkse, Ragnar (1946), The Course and Control of Inflation, Geneva:
Jeague of Nations.

OECD (1983), The Internationalization of Banking, Paris.

Padoa-Schioppa, Tommaso (1985), "Policy Cooperation and the FMS

Experience," in Buiter and Marston (1985), pp. 331-355.

Portes, Richard (1977), "East Europe's Debt to the West," Foreign

Affairs 55, pp. 751-782.

Portes, Richard (1982), "La crise polonaise et les relations economiques est-ouest," Politique etrangere, no. 1, p. 75-90.

Portes, Richard (1986), "Finance, Trade and Development: Issues in Transatlantic Cooperation," CFPR Discussion Paper No. 100. 
Rogoff, Kenneth (1985), "Can Exchange Rate Predictability be Achieved without Monetary Convergence? Evidence from the EMS," European Economic Review 28, pp. 93-116.

Royal Institute of International Affairs (1937), The Problem of Foreign Investment, London: Oxford University Press.

Sachs, Jeffrey (1982), "LDC Debt in the 1980s: Risk and Reforms," in Crises in the Economic and Financial Structure, ed. Paul

Wachtel, Lexington, Mass.: D.C. Heath.

Sachs, Jeffrey (1985), "External Debt and Macroeconomic Performance in Latin America and East Asia," Brookings Papers on Economic

Activity No. 2, pp.523-564.

Securities and Exchange Commission (1937), Report on the Study and Investigation of the Work, Activities, Personnel and Functions of Protective and Reorganization Committees, Washington, D.C., G.P.O.

Solow, Robert (1982), "On the Lender of Last Resort", in Kindleberger and Laffargue (1982), pp. 237-247.

Spero, Joan (1980), The Failure of the Franklin National Bank, New York: Columbia University Press.

State of Vermont (1930), Annual Report of the Bank Commissioner of the State of Vermont for the Year Ending June 30, 1930, Rut Iand, Vermont: The Tuttle company.

Thorp, Rosemary (1984), ed., Latin America in the 1930s, London: Macmillan.

Urquhart, M.C. and K.A.H. Buckley (1965), Historical Statistics of Canada, Cambridge: Cambridge University Press.

U.S. Department of Commerce (1930), American Underwriting of Foreign Securities, Washington, D.C.: G.P.O.

White, Eugene (1984), "A Reinterpretation of the Banking Crisis of $1930, "$ Journal of Economic History XLIV, pp.119-138.

Williamson, John (1977), The Failure of World Monetary Reform, London: Nelson.

Williamson, John (1985), The Exchange Rate System, Washington, DC: Institute for International Economics.

Winkler, Max (1933), Foreign Bonds: An Autopsy, Philadelphia: Roland Swain.

World Bank (1986), World Debt Tables, Washington, DC: IBRD. 